\title{
Evaluation of organic fractions of municipal solid waste as renewable feedstock for succinic acid production
}

\section{Eleni Stylianou}

Agricultural University of Athens

Chrysanthi Pateraki ( $\triangle$ paterakichr@aua.gr)

Agricultural University of Athens

\section{Dimitrios Ladakis}

Agricultural University of Athens

\section{María Cruz Fernández}

IMECAL SA

\section{Marcos Latorre-Sánchez \\ IMECAL SA}

\section{Caterina Coll}

IMECAL SA

\section{Apostolis Koutinas}

Agricultural University of Athens

\section{Research}

Keywords: succinic acid, organic fraction of municipal solid waste, continuous fermentation, Actinobacillus succinogenes, bioprocess, techno-economic evaluation

Posted Date: March 31st, 2020

DOI: https://doi.org/10.21203/rs.2.21810/v2

License: (a) This work is licensed under a Creative Commons Attribution 4.0 International License. Read Full License

Version of Record: A version of this preprint was published at Biotechnology for Biofuels on April 15th, 2020. See the published version at https://doi.org/10.1186/s13068-020-01708-w. 


\section{Abstract}

Background: Despite its high market potential, bio-based succinic acid production experienced recently a declining trend because the initial investments did not meet the expectations for rapid market growth. Thus, reducing the succinic acid production cost is imperative to ensure industrial implementation. Results: Succinic acid production has been evaluated using hydrolysates from the organic fraction of municipal solid waste (OFMSW) collected from MSW treatment plants. A tailor-made enzymatic cocktail was used for OFMSW hydrolysate production containing up to $107.3 \mathrm{~g} / \mathrm{L}$ carbon sources and up to 638.7 $\mathrm{mg} / \mathrm{L}$ free amino nitrogen. The bacterial strains Actinobacillus succinogenes and Basfia succiniciproducens were evaluated for succinic acid production with the latter strain being less efficient due to high lactic acid production. Batch A. succinogenes cultures supplemented with $5 \mathrm{~g} / \mathrm{L}$ yeast extract and $5 \mathrm{~g} / \mathrm{L} \mathrm{MgCO} 3$ reached $29.4 \mathrm{~g} / \mathrm{L}$ succinic acid with productivity of $0.89 \mathrm{~g} / \mathrm{L} / \mathrm{h}$ and yield of $0.56 \mathrm{~g} / \mathrm{g}$. Continuous cultures at dilution rate of $0.06 \mathrm{~h}-1$ reached $21.2 \mathrm{~g} / \mathrm{L}$ succinic acid with yield of $0.47 \mathrm{~g} / \mathrm{g}$ and productivity of $1.27 \mathrm{~g} / \mathrm{L} / \mathrm{h}$. Downstream separation and purification of succinic acid was achieved by centrifugation, treatment with activated carbon, acidification with cation exchange resins, evaporation and drying, reaching more than $99 \%$ purity. Preliminary techno-economic evaluation has been employed to evaluate the profitability potential of bio-based succinic acid production. Conclusions: The use of OFMSW hydrolysate in continuous cultures could lead to a minimum selling price of $2.5 \$ / \mathrm{kg}$ at annual production capacity of $40,000 \mathrm{t}$ succinic acid and OFMSW hydrolysate production cost of $25 \$$ / t sugars.

\section{Background}

In the period 2013-2017, the average annual MSW production in EU was $482 \mathrm{~kg} / \mathrm{capita}$ and 245.3 million $\mathrm{t}$, with the top five producing countries being Germany (20.9\%), France (14\%), UK (12.7\%), Italy $(12.1 \%)$ and Spain (8.7\%) [1]. The composition of MSW varies among EU countries consisting mainly of organic material (25 - 48\%), paper (16 - 51\%), plastics (0.8 - 23.7\%), glass/ceramic (4.5 - 16\%), metals (2 - 8.8\%) and textiles and other components $(3.1-32.2 \%)$ [1]. The main management practices of MSW in EU countries are material recycling, incineration, composting and landfilling. Energy recovery from MSW in EU-28 was on average $24.7 \%$ for the period 2013-2017 [1], with the top 5 countries being Norway (53.7\%), Denmark (53.2\%), Sweden (51.8\%), Finland (50\%) and Estonia (48.7\%). In the EU, the organic fraction of municipal solid waste (OFMSW) or municipal biowaste is defined as the biodegradable garden and park waste, food and kitchen waste from households, offices, restaurants, wholesale, canteens, caterers and retail premises and comparable waste from food processing plants according to the EU Directive $2018 / 851$ [2]. The biowaste fraction constitutes $30-40 \%$ (or even $20-80 \%$ ) of the total MSW [3]. The carbohydrate content of OFMSW is 30-60 \% depending on the origin of the waste and the region among other factors. The OFMSW has been evaluated for the production of polyhydroxyalkanoates (PHAs), biogas and biohydrogen via mixed cultures $[4,5,6]$ as well as the production of bio-based fuels and platform chemicals, such as bioethanol, lactic acid and succinic acid, via single strain fermentations $[7,8,9]$. 
Besides the traditional food and pharmaceutical markets, succinic acid is used for the production of biobased plasticisers, poly(butylene succinate), polyester polyols, coatings, lubricants, resins and personal care products. Succinic acid can be used as platform chemical for the production of 1,4-butanediol, tetrahydrofurane and $y$-butyrolactone among other chemicals [10]. Despite the high potential of succinic acid as platform chemical and the high prospects for industrial growth, in recent years, the growth of biobased succinic acid production is declining because the four initial industrial producers (i.e. Myriant, BioAmber, Reverdia and Succinity) have faced severe competition with low petroleum prices due to increased supply of shale oil and gas that reduced the price of petrochemicals $[11,12,13]$. Although BioAmber closed the production plant in Sarnia (Canada), the company LCY Biosciences that purchased the facility will restart succinic acid production [14]. The facilities of Myriant and Succinity are currently idle, with Reverdia's succinic acid production facility being the only operational one [13]. The market price of bio-based succinic acid $(2.94 \$ / \mathrm{kg})$ is higher than the market price of the combined bio- and fossilbased succinic acid $(2.5 \$ / \mathrm{kg})$ [10]. The cost of bio-based succinic acid production could be reduced through the utilisation of crude renewable resources that can support its production at high capacities to benefit from economies of scale. Within a circular economy context, the OFMSW constitutes a cheap and widely available feedstock the carbohydrate content of which could be relatively easily hydrolysed for succinic acid production.

Succinic acid production has been studied using various types of food waste collected from biowaste bins provided by municipalities containing also other organic materials [9], catering services [15] or specific types of food waste, such as waste bread [16]. Babaei et al., [9] used biowaste hydrolysates collected at source in bins as fermentation feedstock in Basfia succiniproducens cultures for the production of $36 \mathrm{~g} / \mathrm{L}$ succinic acid concentration with yield lower than $0.4 \mathrm{~g} / \mathrm{g}$ and productivity lower than $0.3 \mathrm{~g} / \mathrm{L} / \mathrm{h}$. Li et al. [15] reported the production of $18.9 \mathrm{~g} / \mathrm{L}$ succinic acid concentration with yield of $0.38 \mathrm{~g} / \mathrm{g}$ and productivity of $0.25 \mathrm{~g} / \mathrm{L} / \mathrm{h}$ when a genetically engineered Yarrowia lipolytica strain was cultivated in mixed food waste hydrolysate. The hydrolysis of food waste or biowaste fractions has been mainly carried out using either enzyme consortia produced on-site (e.g. via solid state fungal fermentation) [17] or commercial enzyme mixtures $[9,18]$. The succinic acid production cost could be reduced further by combining the utilisation of low-cost feedstock with continuous fermentations that leads to high productivities $[19,20]$.

The production of succinic acid has never been evaluated using the OFMSW separated in central MSW management facilities, which is currently the predominant worldwide management practice. The combination of industrially optimized tailor-made enzyme mixtures for OFMSW hydrolysis with succinic acid production via fermentation has also not been evaluated in literature-cited publications. Furthermore, continuous cultures for the production of succinic acid from OFMSW hydrolysates have not been evaluated in comparison to fed-batch cultures. This study has evaluated all the aforementioned aspects including the estimation of the threshold of OFMSW pretreatment cost in order to achieve a costcompetitive process for the production of succinic acid crystals of high purity. The widely studied wildtype bacterial strains Actinobacillus succinogenes and B. succiniciproducens have been used in this 
study to provide a comparison basis with literature-cited succinic acid production efficiencies achieved by these strains on various crude hydrolysates.

\section{Results And Discussion}

\section{OFMSW composition}

Table 1 presents the composition of different OFMSW samples used to prepare the OFMSW hydrolysates. Non-biodegradable materials contained in OFMSW (glass, stones, plastics, sand, etc.) can cause serious technological problems in industrial facilities (clogging, erosion in equipment) and reduce the performance of biological processes. Unsorted biowaste obtained via mechanical sorting processing using mixed MSW from household bins contained higher contents of inert material (non-biodegradable) and ash as well as lower moisture content than sorted biowaste. The glucan content, representing both cellulose and starch, is slightly higher in sorted biowaste (ca. $40 \%$, db). Most of glucan originates from cellulose since the obtained starch content is $4-5.3 \%$ in all cases. The xylan content was lower than $5 \%$ $(\mathrm{db})$ in sorted biowaste, while it was higher than $5 \%(\mathrm{db})$ in unsorted biowaste. The pectin content, originating mainly from fruit waste, is lower $(10.1-12.19 \%, \mathrm{db})$ in unsorted biowaste than sorted biowaste $(15.87-18.25 \%$, db). The protein was higher $(8.75-10.15 \%, \mathrm{db})$ in sorted biowaste, while the fat content $(4.59-5.86 \%, \mathrm{db})$ was higher in unsorted biowaste. The lignin content varies $(5.64-11.02$ $\%, \mathrm{db}$ ) among all OFMSW samples. This low content of lignin in municipal biowaste is advantageous compared with other lignocellulosic wastes (typically $>25 \%$ in woods).

The primary components of sorted municipal solid waste are cellulose (45\%), hemicellulose (9\%) and lignin (10\%) [21]. Garcia et al. [22] characterized different fractions of biodegradable municipal solid waste (meat, fish, fruit and vegetable, restaurant and household waste). Dry matter, ash content and crude protein in the different fractions varied between $11.9-59.0 \%, 4.9-21.8 \%$ and $11.6-57.0 \%$ (on a dry basis, db), respectively [22].

\section{OFMSW hydrolysate production}

OFMSW mechanical pretreatment and enzymatic hydrolysis was performed by IMECAL S.A. with tailormade enzymatic cocktails provided by Novozymes. The enzyme content and the corresponding enzyme activities are confidential and cannot be mentioned in this publication. Glucan content (including both cellulose and starch) varied in the range of $25-40 \%(\mathrm{db})$ and xylan content ranged from $0.2-8.7 \%$ (db). Glucan (cellulose and starch) hydrolysis conversion yield was $75 \%(w / w)$ and xylan conversion yield was around $12.5 \%(\mathrm{w} / \mathrm{w})$. Table 2 presents the variation in the composition of different batches of OFMSW hydrolysates produced in this study. The total dry weight measured after hydrolysis was in the range of $114.17-118.81 \mathrm{~g} / \mathrm{L}$ in all cases. In the liquid fraction, the total sugar concentration in OFMSW hydrolysate ranged between 31.2 - $107.3 \mathrm{~g} / \mathrm{L}$ with $70.7-81.3 \%$ glucose $(25.4-75.9 \mathrm{~g} / \mathrm{L}), 7.1-12.6 \%$ xylose $(3.95-7.6 \mathrm{~g} / \mathrm{L})$ and 0.3 to $14.4 \%$ fructose $(0.1-15.5 \mathrm{~g} / \mathrm{L})$. Glycerol, sucrose, galactose, arabinose, mannose concentrations were less than $5 \%$ of the total sugar content. Free amino nitrogen 
(FAN) and inorganic phosphorus (IP) concentrations in the liquid fraction of OFMSW ranged between $203.6-638.7 \mathrm{mg} / \mathrm{L}$ and $100.6-553 \mathrm{mg} / \mathrm{L}$, respectively.

Significant lactic acid concentrations $(10.7-18.6 \mathrm{~g} / \mathrm{L})$ and lower acetic acid concentrations $(1.5-3.7$ $\mathrm{g} / \mathrm{L}$ ) were detected in all OFMSW hydrolysates. These organic acids were present since the beginning of the hydrolysis indicating contamination of OFMSW despite the origin of biowaste streams. No organic acid production or bacterial growth was observed during hydrolysis due to the aseptic conditions used. Furfural and 5-hydroxymethylfurfural were not detected in OFMSW hydrolysates. This was expected as these inhibitory compounds can be generated from the degradation of xylose and glucose under intensive chemical treatment.

In the solid fraction that remained after OFMSW hydrolysis, the ash $(5.7-25 \%$, db) and protein $(7-19.85$ $\%, \mathrm{db})$ contents varied at a wide range depending on the origin of OFMSW. The lipid content was $6.8-7.6$ $\%(\mathrm{db})$. Water and ethanol soluble extractives were ca. $33 \%(\mathrm{db})$. Lignin, cellulose and hemicellulose ranged from $16.92-27.39 \%, 9.07-9.46 \%$ and $12.01-12.37 \%(d b)$, respectively. Hemicellulose consisted of xylan, galactan and mannan fractions.

\section{Batch fermentations}

Table 3 presents succinic acid production via fermentation using $B$. succiniciproducens and $A$. succinogenes at different initial total carbon source concentrations using either commercial carbon sources or OFMSW hydrolysate. Fermentations using the OFMSW hydrolysate enhanced the productivity of both microorganisms compared to the commercial medium, with $52 \%$ increase on average in the case of $B$. succiniciproducens and $32 \%$ in the case of A. succinogenes (Table 3 ). The highest succinic acid concentration that was observed in the case of $B$. succiniciproducens fermentations was $37.1 \mathrm{~g} / \mathrm{L}$ in OFMSW hydrolysate and in the case of $A$. succinogenes was $37.9 \mathrm{~g} / \mathrm{L}$ both in OFMSW hydrolysate and commercial substrate (Table 3 ).

The by-product to succinic acid ratio decreased with increasing initial total carbon source concentration for both $A$. succinogenes and $B$. succiniciproducens in both fermentation media. $B$. succiniciproducens resulted in a decrease of by-product to succinic acid ratio at around $50 \%$ in the case of glucose-based fermentations and up to $25 \%$ in the case of OFMSW hydrolysate. A. succinogenes by-product to succinic acid ratio decreased up to $84 \%$ in the case of glucose and up to $65 \%$ in the case of OFMSW hydrolysate (Table 3). The major difference between the two microorganisms lies on the fact that lactic acid production from $B$. succiniciproducens occurs throughout fermentation. When OFMSW hydrolysates were used, lactic acid and acetic acid were present at the beginning of fermentation and they have been excluded from the ratios presented in Table 3.

Figure 1 presents experimental results of batch fermentation carried out with $A$. succinogenes using OFMSW hydrolysate at initial total sugar concentration of $80 \mathrm{~g} / \mathrm{L}$. The final succinic acid concentration was $37.9 \mathrm{~g} / \mathrm{L}$ with yield of $0.5 \mathrm{~g} / \mathrm{g}$ and productivity of $0.57 \mathrm{~g} / \mathrm{L} / \mathrm{h}$. The initial FAN concentration using both the synthetic medium and the OFMSW hydrolysate was in the range of $251-285 \mathrm{mg} / \mathrm{L}$ in all batch 
fermentations. FAN consumption occurred in the first $24 \mathrm{~h}$ and remained constant (at around $100 \mathrm{mg} / \mathrm{L}$ ) until the end of fermentation (Figures 1a).

Babaei et al. [9] carried out batch fermentations with $B$. succiniciproducens cultivated in a hydrolysate from the organic fraction of household kitchen waste (the sugars contained $85 \%$ glucose and $15 \%$ xylose) with $\mathrm{CO}_{2}$ supply from either $\mathrm{MgCO}_{3}$ or raw biogas. Succinic acid production efficiency of around $5.5 \mathrm{~g} / \mathrm{L}$ with yield $0.39 \mathrm{~g} / \mathrm{g}$ and $3.8 \mathrm{~g} / \mathrm{L}$ with yield $0.25 \mathrm{~g} / \mathrm{g}$, respectively [9]. A. succinogenes has been employed for succinic acid production using deacetylated dilute acid pretreated corn stover hydrolysate leading to the production of $42.8 \mathrm{~g} / \mathrm{L}$ succinic acid with yield of $0.74 \mathrm{~g} / \mathrm{g}$ and maximum productivity of $1.27 \mathrm{~g} / \mathrm{L} / \mathrm{h}$ [23]. Glucose rich food waste have also been used for the production of succinic acid in batch cultures by an engineered Yarrowia lipolytica strain resulting in $31.7 \mathrm{~g} / \mathrm{L}$ succinic acid concentration with yield of $0.52 \mathrm{~g} / \mathrm{g}$ and productivity of $0.60 \mathrm{~g} / \mathrm{L} / \mathrm{h}$ [24]. Waste bread and bakery waste hydrolysates have also been used as raw materials for the production of succinic acid. Fermentation with bakery waste by A. succinogenes resulted in $47.3 \mathrm{~g} / \mathrm{L}$ succinic acid with a yield of $1.16 \mathrm{~g} / \mathrm{g}$ glucose and productivity of $1.12 \mathrm{~g} / \mathrm{L} \mathrm{h}$ [25]. Cake and pastry hydrolysates resulted in $24.8 \mathrm{~g} / \mathrm{L}$ (yield $0.8 \mathrm{~g} / \mathrm{g}$, productivity $0.79 \mathrm{~g} / \mathrm{L} / \mathrm{h}$ ) and $31.7 \mathrm{~g} / \mathrm{L}$ (yield $0.67 \mathrm{~g} / \mathrm{g}$, productivity $0.87 \mathrm{~g} / \mathrm{L} / \mathrm{h}$ ) succinic acid concentration, respectively [26].

From a techno-economic viewpoint, it is crucial to identify the initial carbon source concentration in bioreactor cultures leading to the highest succinic acid concentration, yield and productivity. Results from this study clearly demonstrate that OFMSW hydrolysates at a $50 \mathrm{~g} / \mathrm{L}$ initial carbon source concentration resulted in the highest productivity and yield for both microorganisms. Liu et al. [27] reported that growth inhibition of $A$. succinogenes was observed at $50 \mathrm{~g} / \mathrm{L}$ initial glucose concentration. Salvachua et al. [23] carried out batch fermentations at different initial glucose concentrations (40-100 g/L) with the highest yield $(0.72 \mathrm{~g} / \mathrm{g})$ achieved at initial glucose concentration of $60 \mathrm{~g} / \mathrm{L}$. $A$. succinogenes can tolerate up to $143 \mathrm{~g} / \mathrm{L}$ glucose and cell growth was completely inhibited when glucose concentration was higher than $158 \mathrm{~g} / \mathrm{L}$ [28]. However, significant decrease of yield and prolonged lag phase were observed when glucose concentration was higher than $100 \mathrm{~g} / \mathrm{L}$ [28]. Using a xylose based medium, the initial inhibitory sugar concentration was around $50 \mathrm{~g} / \mathrm{L}$ for both $A$. succinogenes and B. succiniciproducens [29].

Subsequent fed-batch fermentations on OFMSW hydrolysates were carried out with $A$. succinogenes at ca. $50 \mathrm{~g} / \mathrm{L}$ initial carbon source concentration, where yield, productivity and by-product to succinic acid ratio were optimum. $B$. succiniciproducens was not selected due to significant lactic acid production during fermentation.

\section{Fed-batch bioreactor fermentations}

Table 4 presents the succinic acid production efficiency of $A$. succinogenes in fed-batch fermentations using OFMSW hydrolysate. Evaluation of the effect of different initial $\mathrm{MgCO}_{3}$ concentration $(5,10,20$ $\mathrm{g} / \mathrm{L}$ ) resulted in moderate improvement of succinic acid production efficiency at increasing concentrations. The highest succinic acid concentration $(34.8 \mathrm{~g} / \mathrm{L})$, yield $(0.6 \mathrm{~g} / \mathrm{g})$ and productivity $(0.79$ $\mathrm{g} / \mathrm{L} / \mathrm{h}$ ) were achieved when $20 \mathrm{~g} / \mathrm{L} \mathrm{MgCO}_{3}$ concentration was used. The production of metabolic by- 
products was slightly reduced when $\mathrm{MgCO}_{3}$ concentration was increased to $10 \mathrm{~g} / \mathrm{L}$. Magnesium ions act as a cofactor for the key enzyme phosphoenolpyruvate (PEP) carboxykinase [30] and carbonate ions $\left(\mathrm{HCO}_{3}{ }^{-}, \mathrm{CO}_{3}{ }^{2-}\right)$ are a pool of additional $\mathrm{CO}_{2}[31] . \mathrm{CO}_{2}$ in the form of gas or carbonate salts have been previously investigated by McKinlay et. al. [32] resulting in increased succinic acid concentration in favor of by-product accumulation due to the suppression of OAAdec and Maldec towards pyruvate. According to Brink et al. [33], A. succinogenes is able to metabolize formate to $\mathrm{CO}_{2}$ and $\mathrm{H}_{2} \mathrm{O}$ towards the production of NADH. As a result, the generation of NADH contributes to enhanced succinic acid production. However, significant enhancement of succinic acid production efficiency was not observed in this study at high $\mathrm{MgCO}_{3}$ concentrations. For this reason, the lowest $\mathrm{MgCO}_{3}$ concentration $(5 \mathrm{~g} / \mathrm{L})$ was used in subsequent fermentations in order to minimize raw material cost and environmental impact.

Figure 2 presents the metabolic product formation and lactic acid accumulation during fed-batch cultures carried out with different initial $\mathrm{MgCO}_{3}$ concentrations. Lactic acid (Figure 2) accumulation due to feeding of OFMSW hydrolysate reached concentrations close to $10 \mathrm{~g} / \mathrm{L}$ when higher $\mathrm{MgCO}_{3}$ concentrations were used. The lactic acid concentration in batch cultures with $50 \mathrm{~g} / \mathrm{L}$ initial carbon source concentration from OFMSW hydrolysates was constant $(10 \mathrm{~g} / \mathrm{L})$ during fermentation resulting in higher productivity $(0.89 \mathrm{~g} / \mathrm{L} / \mathrm{h})$ and similar yield $(0.56 \mathrm{~g} / \mathrm{g})$ (Table 3$)$ as compared to fed-batch cultures carried out with $5 \mathrm{~g} / \mathrm{L}$ and $10 \mathrm{~g} / \mathrm{L}$ initial $\mathrm{MgCO}_{3}$ concentration.

Yeast extract (YE) and corn steep liquor (CSL) supplementation was also evaluated in fed-batch fermentations using OFMSW hydrolysate supplemented with $5 \mathrm{~g} / \mathrm{L} \mathrm{MgCO}$ (Figure 3). Addition of $5 \mathrm{~g} / \mathrm{L}$ $\mathrm{CSL}$ resulted in $28.7 \mathrm{~g} / \mathrm{L}$ of succinic acid with a yield of $0.5 \mathrm{~g} / \mathrm{g}$ and a productivity of $0.41 \mathrm{~g} / \mathrm{L} / \mathrm{h}$. Yeast extract supplementation $(5 \mathrm{~g} / \mathrm{L})$ resulted in significantly higher succinic acid concentration $(34.3 \mathrm{~g} / \mathrm{L})$ and productivity $(0.75 \mathrm{~g} / \mathrm{L} / \mathrm{h})$. However, the utilisation of yeast extract resulted in the highest by-product to succinic acid ratio (0.59) among all fed-batch fermentations presented in Table 4.

Yeast extract enhances cells growth and succinic acid production. Liu et al. [27] reported that yeast extract results in slightly higher succinic acid concentration than CSL in A. succinogenes CGMCC1593 cultures. CSL derived from corn refining has been widely employed as the sole nitrogen source resulting in high succinic acid concentrations (47.4 g/L) [34]. Chen et al. [35] reported the production of $35.5 \mathrm{~g} / \mathrm{L}$ succinic acid in $A$. succinogenes cultures carried out with $50 \mathrm{~g} / \mathrm{L}$ glucose concentration and spent yeast cell hydrolysate, with a glucose utilization of $95.2 \%$.

\section{Continuous fermentation}

Figure 4 presents carbon source consumption and metabolic product accumulation during continuous fermentation of $A$. succinogenes. The continuous culture was carried out with glucose as carbon source until $900 \mathrm{~h}$, since the major sugar fraction in OFMSW hydrolysate is glucose (73.2 \%). OFMSW hydrolysate was used as feeding solution from $900 \mathrm{~h}$ until $2400 \mathrm{~h}$. At $237 \mathrm{~h}$, biofilm formation was developed and thus steady-state conditions were established. Three dilution rates $\left(0.02,0.04\right.$ and $0.08 \mathrm{~h}^{-}$ $\left.{ }^{1}\right)$ were used with glucose and 6 dilution rates $\left(0.02,0.04,0.05,0.06,0.08\right.$ and $\left.0.1 \mathrm{~h}^{-1}\right)$ were used with 
OFMSW hydrolysate. Figure 4 shows that steady-state was achieved within $2-4$ days depending on the dilution rate used.

Using glucose and a dilution rate of $0.02 \mathrm{~h}^{-1}$, the average succinic acid production was $23.1 \mathrm{~g} / \mathrm{L}$ with a yield of $0.51 \mathrm{~g} / \mathrm{g}$ (Figure 5). Succinic acid concentration slightly decreased at increasing dilution rates. Specifically, it was $22.5 \mathrm{~g} / \mathrm{L}(0.50 \mathrm{~g} / \mathrm{g}$ yield $)$ and $21.2 \mathrm{~g} / \mathrm{L}(0.47 \mathrm{~g} / \mathrm{g}$ yield $)$ at dilution rates of $0.04 \mathrm{~h}^{-1}$ and $0.08 \mathrm{~h}^{-1}$, respectively. Increased dilution rates resulted in increased productivity, namely $0.46 \mathrm{~g} / \mathrm{L} / \mathrm{h}, 0.9$ $\mathrm{g} / \mathrm{L} / \mathrm{h}$ and $1.71 \mathrm{~g} / \mathrm{L} / \mathrm{h}$ at dilution rates of $0.02 \mathrm{~h}^{-1}, 0.04 \mathrm{~h}^{-1}$ and $0.08 \mathrm{~h}^{-1}$, respectively.

OFMSW hydrolysate resulted in an average succinic acid production of $23.8 \mathrm{~g} / \mathrm{L}$ with a yield of $0.53 \mathrm{~g} / \mathrm{g}$ at dilution rate $0.02 \mathrm{~h}^{-1}$ (Figure 5). Succinic acid concentration $(23.5-23.1 \mathrm{~g} / \mathrm{L})$ and yield $(0.52-0.51 \mathrm{~g} / \mathrm{g}$ ) were stable at $0.04 \mathrm{~h}^{-1}$ and $0.05 \mathrm{~h}^{-1}$. Higher dilution rates resulted in decreasing succinic acid concentration and yield. Specifically, succinic acid concentration was $21.2 \mathrm{~g} / \mathrm{L}, 17.7 \mathrm{~g} / \mathrm{L}$ and $10 \mathrm{~g} / \mathrm{L}$ at dilution rates of $0.06 \mathrm{~h}^{-1}, 0.08 \mathrm{~h}^{-1}$ and $0.1 \mathrm{~h}^{-1}$, respectively. The productivity increased at increasing dilution rates, up to $0.08 \mathrm{~h}^{-1}$, with an average productivity of $0.48 \mathrm{~g} / \mathrm{L} / \mathrm{h}, 0.94 \mathrm{~g} / \mathrm{L} / \mathrm{h}, 1.16 \mathrm{~g} / \mathrm{L} / \mathrm{h}, 1.27$ $\mathrm{g} / \mathrm{L} / \mathrm{h}$, and $1.41 \mathrm{~g} / \mathrm{L} / \mathrm{h}$ at dilution rates of $0.02 \mathrm{~h}^{-1}, 0.04 \mathrm{~h}^{-1}, 0.05 \mathrm{~h}^{-1}, 0.06 \mathrm{~h}^{-1}$ and $0.08 \mathrm{~h}^{-1}$, respectively. Significant decrease in succinic acid production efficiency was observed at $0.1 \mathrm{~h}^{-1}$ due to cell wash-out.

Formic and acetic acid production was observed throughout continuous fermentation carried out either with glucose or OFMSW hydrolysate (Figure 4b). In the latter case, lactic acid accumulation was observed due to its presence in the OFMSW hydrolysate. Acetic acid concentrations produced by $A$. succinogenes were $7.1 \mathrm{~g} / \mathrm{L}, 5.9 \mathrm{~g} / \mathrm{L}$ and $5.4 \mathrm{~g} / \mathrm{L}$ at dilution rates $0.02,0.04$ and $0.08 \mathrm{~h}^{-1}$, respectively, in glucose based medium. The respective formic acid concentrations were $5.7 \mathrm{~g} / \mathrm{L}, 4.8 \mathrm{~g} / \mathrm{L}$ and $4.4 \mathrm{~g} / \mathrm{L}$. The by-products to succinic acid ratio in glucose at dilution rate of $0.02 \mathrm{~h}^{-1}$ was $0.55 \mathrm{~g} / \mathrm{g}$, while at increasing dilution rates $\left(0.04\right.$ and $\left.0.08 \mathrm{~h}^{-1}\right)$ by-products to succinic acid ratio was around $0.46 \mathrm{~g} / \mathrm{g}$.

When A. succinogenes was cultivated on OFMSW hydrolysate, the acetic acid concentration was always higher than formic acid concentrations at all dilution rates. The highest acetic acid concentrations were observed at dilution rates of $0.02 \mathrm{~h}^{-1}(9.9 \mathrm{~g} / \mathrm{L})$ and $0.04 \mathrm{~h}^{-1}(9.3 \mathrm{~g} / \mathrm{L})$. The highest concentration of total by-products for $A$. succinogenes was observed at dilution rate of $0.02 \mathrm{~h}^{-1}(12.7 \mathrm{~g} / \mathrm{L}$ in glucose and $18 \mathrm{~g} / \mathrm{L}$ in OFMSW hydrolysate). By-products to succinic acid ratio using OFMSW hydrolysate as feeding was $0.76 \mathrm{~g} / \mathrm{g}, 0.73 \mathrm{~g} / \mathrm{g}, 0.71 \mathrm{~g} / \mathrm{g}, 0.62 \mathrm{~g} / \mathrm{g}, 0.63 \mathrm{~g} / \mathrm{g}$ and $0.6 \mathrm{~g} / \mathrm{g}$ at dilution rates of $0.02 \mathrm{~h}^{-1}, 0.04 \mathrm{~h}^{-1}, 0.05 \mathrm{~h}^{-1}$, $0.06 h^{-1}, 0.08 h^{-1}$ and $0.1 h^{-1}$, respectively.

Biofilm formation occurred on the wall and the mechanical parts of the bioreactor during continuous fermentation (Figure 6). Continuous $A$. succinogenes cultures under prolonged operation period result in biofilm formation [36, 37, 38]. Ladakis et al. [19] carried out continuous $A$. succinogenes fermentation using synthetic xylose as carbon source leading to succinic acid concentration of $24 \mathrm{~g} / \mathrm{L}$ with yield 0.6 $\mathrm{g} / \mathrm{g}$ at $0.02 \mathrm{~h}^{-1}$. Higher yield $(0.77 \mathrm{~g} / \mathrm{g})$ and succinic acid concentration $(26.4 \mathrm{~g} / \mathrm{L})$ was achieved in continuous cultures of immobilized $A$. succinogenes cells using synthetic xylose at dilution rate $0.1 \mathrm{~h}^{-1}$ 
[20]. Continuous $A$. succinogenes cultures carried out on glucose at dilution rate $0.11 \mathrm{~h}^{-1}$ in a biofilm reactor packed with Poraver ${ }^{\circledR}$ beads led to $29.5 \mathrm{~g} / \mathrm{L}$ succinic acid concentration with productivity of 3.24 $\mathrm{g} / \mathrm{L} / \mathrm{h}$ and yield of $0.9 \mathrm{~g} / \mathrm{g}$ [39]. Ferone et al. [40] reported continuous succinic acid fermentation of $A$ succinogenes in a packed-bed biofilm reactor leading to $43 \mathrm{~g} / \mathrm{L}$ succinic acid concentration at dilution rate $0.5 \mathrm{~h}^{-1}$ with glucose conversion of $88 \%$. Continuous $A$. succinogenes cultures on glucose conducted in a fibrous-bed bioreactor led to $55.3 \mathrm{~g} / \mathrm{L}$ succinic acid concentration with $0.8 \mathrm{~g} / \mathrm{g}$ yield and $2.77 \mathrm{~g} / \mathrm{L} / \mathrm{h}$ production at dilution rate $0.05 \mathrm{~h}^{-1}[41]$.

Various crude hydrolysates from various biomass sources have been used for the production of biobased succinic acid. Continuous fermentation on spent sulfite liquor resulted in $19.2 \mathrm{~g} / \mathrm{L}$ succinic acid concentration with yield $0.48 \mathrm{~g} / \mathrm{g}$ at dilution rate $0.02 \mathrm{~h}^{-1}$, while the highest productivity was $0.68 \mathrm{~g} / \mathrm{L} / \mathrm{h}$ at dilution rate $0.04 \mathrm{~h}^{-1}$ [19]. Brandfield et al. achieved succinic acid concentration of $39.6 \mathrm{~g} / \mathrm{L}$ via immobilized $A$. succinogenes continuous cultures carried out on corn stover hydrolysate [20].

\section{Process feasibility evaluation}

A preliminary techno-economic evaluation was carried out considering the optimum succinic acid production efficiency achieved in batch and continuous $A$. succinogenes cultures using OFMSW hydrolysate as feedstock. The batch fermentation resulted in $29.4 \mathrm{~g} / \mathrm{L}$ succinic acid concentration with yield of $0.56 \mathrm{~g} / \mathrm{g}$ and productivity of $0.89 \mathrm{~g} / \mathrm{L} / \mathrm{h}$ (Table 3 ). In continuous cultures, the succinic acid production efficiency $(21.2 \mathrm{~g} / \mathrm{L}, 0.47 \mathrm{~g} / \mathrm{g}$ yield and $1.27 \mathrm{~g} / \mathrm{L} / \mathrm{h}$ productivity) achieved at dilution rate 0.06 $\mathrm{h}^{-1}$ was used in techno-economic evaluation. Fed-batch fermentations led to $34.3 \mathrm{~g} / \mathrm{L}$ succinic acid concentration with a yield of $0.5 \mathrm{~g} / \mathrm{g}$ and a productivity of $0.75 \mathrm{~g} / \mathrm{L} / \mathrm{h}$. Fed-batch fermentations were not used in the technoeconomic evaluation due to the low productivity achieved.

The design and costing methodology were applied on the fermentation stage including media sterilization and the downstream separation and purification (DSP) stage that included centrifugation, activated carbon treatment, cation exchange resin treatment, evaporation, crystallization and drying unit operations. The estimation of the optimal design of the fermentation stage, the optimal scheduling of unit operations and the cost estimation of unit operations is based on the work presented by Dheskali et al. [42]. The cost of manufacture for succinic acid did not consider the upstream stage of OFMSW pretreatment and hydrolysis. The production cost of OFMSW hydrolysate was subsequently estimated in order to achieve a minimum selling price (MSP) of bio-based succinic acid equal to its market price (2.94 $\$ / \mathrm{kg}$ according to [12]) or a potential market price of $2.5 \$ / \mathrm{kg}$ at varying annual succinic acid production capacities (Figure 7). In this way, the profitability potential of succinic acid production could be assessed considering variable production cost for OFMSW derived carbon sources.

The cost of manufacture for bio-based succinic acid, considering only fermentation and DSP stages, is reduced at a lower rate for both continuous and batch cultures at annual capacity higher than $50,000 \mathrm{t}$ (Figure 7a). This occurs because economies of scale have been reached. The implementation of continuous cultures leads to slightly lower cost of manufacture than batch cultures. Figure $7 \mathrm{~b}$ shows the 
production cost of OFMSW-derived sugars that should be achieved at varying succinic acid production capacities in order to satisfy minimum selling prices of $2.94 \$ / \mathrm{kg}$ and $2.5 \$ / \mathrm{kg}$. This means that if a lower OFMSW-derived sugar production cost than the one presented in Figure $7 \mathrm{~b}$ at a specific plant capacity is achieved, then lower MSP than the targeted one could be reached. For instance, if an OFMSW hydrolysate production cost of $230 \$ / t$ total sugars is assumed, which is close to the market price of glucose syrup derived through enzymatic hydrolysis of corn starch produced by the wet milling process, then a MSP equal to the current market price of bio-based succinic acid $(2.94 \$ / \mathrm{kg})$ could be achieved at annual succinic acid production capacity of $50,000 \mathrm{t}$ if batch cultures are used and 40,000 $\mathrm{t}$ if continuous cultures are used. A MSP equal to $2.5 \$ / \mathrm{kg}$ could be achieved at OFMSW hydrolysate production cost of $25 \$ / t$ total sugars, when the industrial plant produces annually 40,000 t succinic acid via continuous cultures or $60,000 \mathrm{t}$ succinic acid via batch cultures.

\section{Conclusion}

The OFMSW can be considered as a promising feedstock for the production of bio-based succinic acid. Despite the geographical and seasonal variability in OFMSW composition, the utilisation of tailor-made enzymatic cocktails can lead sufficient hydrolysis of OFMSW carbohydrates. Efficient succinic acid production could be achieved in both batch and continuous cultures using OFMSW hydrolysates. Technoeconomic evaluation showed that the utilisation of OFMSW hydrolysates could lead to significantly reduced succinic acid production cost. Further cost reduction is needed though to improve further process profitability.

\section{Methods}

\section{Bacterial strains and inoculum preparation}

The bacterial strains employed for succinic acid production were Basfia succiniciproducens JF 4016 (DSM-22022) and Actinobacillus succinogenes $130 Z$ (DSM - 22257), which were purchased from the Leibniz Institute DSMZ - German Collection of Microorganisms and Cell Cultures. All microorganisms were preserved in cryopreservation vials at $-80^{\circ} \mathrm{C}$ in a medium containing liquid culture and $50 \%(\mathrm{v} / \mathrm{v})$ pure glycerol. Inoculum preparation was carried out in Erlenmeyer flasks in tryptic soya broth (TSB) containing pancreatic digest of casein $(17 \mathrm{~g} / \mathrm{L}), \mathrm{NaCl}(5 \mathrm{~g} / \mathrm{L})$, papaic digest of soy bean $(3 \mathrm{~g} / \mathrm{L}), \mathrm{K}_{2} \mathrm{HPO}_{4}$ $(2.5 \mathrm{~g} / \mathrm{L})$ and glucose $(2.5 \mathrm{~g} / \mathrm{L})$. Inoculum preparation was carried out in an orbital shaker for $16-18 \mathrm{~h}$ at $37^{\circ} \mathrm{C}$ and $180 \mathrm{rpm}$ agitation.

\section{OFMSW origin and hydrolysate preparation}

The following two representative OFMSW streams were collected from an industrial MSW treatment plant in Valencia Metropolitan Area (Spain): 1) "Sorted biowaste" coming from a separate collection in origin from hotels, restaurants, markets and schools (HORECA stream), and 2) "unsorted biowaste" coming from mixed MSW from households bins, after passing different mechanical sorting pre-treatments to 
recover recyclables and before entering in the biological treatment stage of the plant (composting). Municipal biowaste samples ranging from $50-100 \mathrm{~kg}$ were collected from the industrial plant in different periods of the year. Once collected from the plant, the remaining inert materials (glass, plastics, stones, textiles, etc.) were removed by manual sorting. After this, the OFMSW samples were mechanically pretreated and milled in a pilot plant hammer mill by the IMECAL company in order to be homogenized and then sterilized by autoclaving at $121^{\circ} \mathrm{C}$ for $1 \mathrm{~h}$ before submitting to chemical characterization and enzymatic hydrolysis (Figure 8).

The enzymatic hydrolysis was carried out at $20 \%$ solids concentration at $50^{\circ} \mathrm{C}$ and $\mathrm{pH} 5$ for $72 \mathrm{~h}$ at 150 rpm. The used enzyme cocktail, tailor-made for OFMSW hydrolysis, was supplied by Novozymes A/S company. The optimal used cocktail was a mixture of different enzymes able to hydrolyze up to $86 \%$ of glucan and xylan content into fermentable glucose and xylose sugars. The OFMSW hydrolysate was centrifuged ( $9000 \mathrm{rpm}, 4^{\circ} \mathrm{C}, 10 \mathrm{~min}$ ) to remove the solid fraction.

\section{Batch, fed-batch and continuous fermentations}

The effect of initial sugar concentration $(30,50,80 \mathrm{~g} / \mathrm{L})$ was evaluated in batch fermentations using both OFMSW hydrolysate and synthetic medium containing commercial carbon sources in a similar ratio (sucrose $4.3 \%$, glucose $73.2 \%$, fructose $18.4 \%$, mannose $0.9 \%$, arabinose $1.8 \%$, galactose $0.3 \%$ and glycerol $1.2 \%$ ) as the one contained on average in OFMSW hydrolysate. The latter medium was used as control experiment. The synthetic medium and OFMSW hydrolysate for $A$. succinogenes and $B$. succiniciproducens fermentations were supplemented with $5 \mathrm{~g} / \mathrm{L}$ yeast extract and $5 \mathrm{~g} / \mathrm{L} \mathrm{MgCO}_{3}$. The synthetic medium was also supplemented with the following mineral medium: $1.16 \mathrm{~g} / \mathrm{L} \mathrm{NaH} \mathrm{PO}_{4} \cdot \mathrm{H}_{2} \mathrm{O}$, $0.31 \mathrm{~g} / \mathrm{L} \mathrm{Na}_{2} \mathrm{HPO}_{4}, 1 \mathrm{~g} / \mathrm{L} \mathrm{NaCl}, 0.2 \mathrm{~g} / \mathrm{L} \mathrm{MgCl} \cdot 6 \mathrm{H}_{2} \mathrm{O}, 0.2 \mathrm{~g} / \mathrm{L} \mathrm{CaCl} 2 \cdot 2 \mathrm{H}_{2} \mathrm{O}$.

The effect of yeast extract $(5 \mathrm{~g} / \mathrm{L})$, corn steep liquor $(5 \mathrm{~g} / \mathrm{L})$ and different $\mathrm{MgCO}_{3}$ concentrations $(5,10$ and $20 \mathrm{~g} / \mathrm{L}$ ) on succinic acid production efficiency were evaluated in A. succinogenes fed-batch cultures. All fermentations were initiated with ca. $50 \mathrm{~g} / \mathrm{L}$ initial total sugar concentration. The feeding solution used was a concentrated OFMSW hydrolysate obtained via rotary evaporation with a total sugar concentration of $400 \mathrm{~g} / \mathrm{L}$. Feeding was carried out in pulses when the total sugar concentration was reduced to $5-15 \mathrm{~g} / \mathrm{L}$.

Continuous $A$. succinogenes culture was initially operated in batch mode for $24 \mathrm{~h}$ and then continuous operation was initiated. The medium at the beginning of continuous fermentation contained $30 \mathrm{~g} / \mathrm{L}$ glucose, $10 \mathrm{~g} / \mathrm{L}$ yeast extract, $5 \mathrm{~g} / \mathrm{L} \mathrm{MgCO}_{3}$ and minerals (as described in batch cultures). The continuous culture was initially conducted at a dilution rate of $0.02 \mathrm{~h}^{-1}$, with a feeding medium that contained $50 \mathrm{~g} / \mathrm{L}$ glucose, $5 \mathrm{~g} / \mathrm{L}$ yeast extract and minerals, in order to increase bacterial cell concentration and stabilise bioreactor operation. Three dilution rates $\left(0.02,0.04,0.08 \mathrm{~h}^{-1}\right)$ were applied using the same glucose-based synthetic medium. The continuous culture was subsequently operated at different dilution rates $(0.02$, $0.04,0.05,0.06,0.08,0.1 \mathrm{~h}^{-1}$ ) with OFMSW hydrolysate as feeding medium containing a total sugar concentration of $35-50 \mathrm{~g} / \mathrm{L}$. Yeast extract was added (if needed) into the OFMSW hydrolysate used as 
feeding medium in order to adjust the FAN concentration at around $500 \mathrm{mg} / \mathrm{L}$. The dilution rate is expressed as the ratio of the volumetric flow rate of the feeding medium to the working volume of the bioreactor. Each dilution rate lasted for approximately 7-8 hydraulic retention times (HRT).

Batch, fed-batch and continuous fermentations were carried out in $1 \mathrm{~L}$ bench-top bioreactor (Labfors 4 , Infors $\mathrm{HT}$ ) with $0.5 \mathrm{~L}$ working volume. Fermentation $\mathrm{pH}$ was controlled at 6.7 with $5 \mathrm{M} \mathrm{NaOH}$. Inoculum size was $10 \%(\mathrm{v} / \mathrm{v})$. The temperature and agitation were maintained at $37^{\circ} \mathrm{C}$ and $100 \mathrm{rpm}$ throughout fermentation. Continuous supply of $\mathrm{CO}_{2}$ gas at a flow rate of $0.5 \mathrm{vvm}$ was applied. Carbon and nitrogen sources were sterilized separately from the rest of the medium at $121^{\circ} \mathrm{C}$ for 20 min prior to fermentation. Fermentation samples were observed under the microscope to ensure that there was no contamination during fermentation.

\section{Analytical methods}

Bacterial mass concentration was determined by measuring optical density at $660 \mathrm{~nm}$ using a spectrophotometer (U-2000 Hitachi). IP was determined according to [43] and FAN was determined according to [44].

To eliminate excess of $\mathrm{MgCO}_{3}, 7 \% \mathrm{HCl}(\mathrm{v} / \mathrm{v})$ solution was added into each fermentation sample. Sugars, organic acids and potential fermentation inhibitors (e.g. furfural, 5-hydroxymethylfurfural or 5-HMF) were determined using a Shimadzu HPLC system with a Shimadzu RI detector and a Rezex ROA-Organic acid $\mathrm{H}^{+}$column. The temperature of the column was $65^{\circ} \mathrm{C}$ and the mobile phase was a $10 \mathrm{mM} \mathrm{H}_{2} \mathrm{SO}_{4}$ aqueous solution at $0.6 \mathrm{~mL} / \mathrm{min}$ flow rate. Monosaccharides were also determined with a Shodex SP0810 ( 8.0 × $300 \mathrm{~mm})$ column using a Shimadzu HPLC system and Shimadzu RI detector. The temperature of the column was $80 \circ \mathrm{C}$ and the mobile phase was HPLC grade water at flow rate 1.0 $\mathrm{mL} / \mathrm{min}$.

\section{Determination of OFMSW composition}

The compositional analysis was performed in duplicate. Humidity was determined by dying at $105^{\circ} \mathrm{C}$ until constant weight was obtained and the ash content by kiln calcination at $575^{\circ} \mathrm{C}$. Samples were airdried at $40^{\circ} \mathrm{C}$ to a moisture content of about $10 \%$ and then milled using a centrifugal mill to $1 \mathrm{~mm}$ particle size. Carbohydrate content (as glucans and xylans) was determined after a two-step acid hydrolysis according to Sluiter et al. [45]. Starch content was measured using the Total Starch Assay Kit (Megazyme, Ireland) based on the use of thermostable a-amylase and amyloglucosidase. The protein content was determined by two methods: a) by specific staining and spectrophotometry against bovine serum albumin (bicinchoninic acid assay) using Pierce BCA Protein Assay Kit of Thermo Fisher Scientific and b) by the Kjeldahl method using a Tecator digestor and Foss Tecator Kjeltec 8200 Auto Distillation Unit and a Nitrogen-Protein Factor (NF) of 6.25.

The analysis of the remaining components in OFMSW samples was performed as gravimetric analysis in the following sequential steps. The first step was Soxhlet extraction of fat by processing $10 \mathrm{~g}$ material 
and $500 \mathrm{ml}$ chloroform for $1 \mathrm{~h}$, followed by overnight drying at $75^{\circ} \mathrm{C}$. The second step was extraction of water solubles using $3.0 \mathrm{~g}$ of fat free material extracted with water for $0.5 \mathrm{~h}$ at room temperature followed by dry filtration and overnight drying at $75^{\circ} \mathrm{C}$ and weighed. The third step focused on quantitation of pectin by extraction with $3 \%$ EDTA solution, $\mathrm{pH} 4.0$ for $4 \mathrm{~h}$ in an $85^{\circ} \mathrm{C}$ water bath, followed by $500 \mathrm{ml}$ hot water material wash at $50{ }^{\circ} \mathrm{C}$ and overnight drying at $75^{\circ} \mathrm{C}$ and weighed. The fourth step focused on quantification of the lignin content as follows: Approximately $2.0 \mathrm{~g}$ material was stirred in $300 \mathrm{ml}$ water containing $20 \mathrm{~mL}$ of $10 \%$ acetic acid and $10 \mathrm{~g} \mathrm{NaClO}_{2}$, in $75^{\circ} \mathrm{C}$ water bath for $1 \mathrm{~h}$. A $10 \mathrm{~mL}$ of $10 \%$ acetic acid and $5 \mathrm{~g} \mathrm{NaClO}_{2}$ was added after $1 \mathrm{~h}$ and the reaction was stopped by placing the sample in ice water. The sample was filtered through a glass filter and washed three times with $100 \mathrm{ml}$ water at $50{ }^{\circ} \mathrm{C}$, two times with $100 \mathrm{ml}$ ethanol aqueous solution (96\%) and one time with $100 \mathrm{ml}$ acetone. The filtered sample was dried at $75^{\circ} \mathrm{C}$ overnight and weighed.

\section{Determination of the composition of liquid and solid fractions in OFMSW hydrolysate}

Total solids were determined according to Sluiter et al. [46]. $\mathrm{pH}$ was measured with Mettler Toledo $\mathrm{pH}$ meter. Ash content was determined by treating samples at $575^{\circ} \mathrm{C}$ for $4 \mathrm{~h}$ [47]. After separation of the liquid and solid fractions by centrifugation, the following analyses were carried out. The liquid fraction of OFMSW was used for the determination of sugars, organic acids, inhibitors, IP and FAN as reported above.

The solid fraction was freeze dried and was treated with hexane for $4 \mathrm{~h}$ in a Soxhlet apparatus to determine the lipid content. The protein content was determined by Kjeldahl method. Starch was determined with the total starch assay kit (Megazyme, Ireland) according to AOAC Official Method 996.11 and pectin content was determined according to [48]. The OFMSW freeze dried solid fraction was treated with $\mathrm{ddH}_{2} \mathrm{O}$ and ethanol to determine the extractives according to the analytical protocol reported by Sluiter et al. [49]. The dried material that resulted from this treatment was used for determination of structural carbohydrates according to the analytical protocol reported by Sluiter et al. [45].

\section{Preliminary techno-economic evaluation}

The bio-based succinic acid production cost has been estimated via preliminary techno-economic evaluation (accuracy up to $\pm 30 \%$ ). The fermentation stage including sterilization and the DSP have been considered for the estimation of the production cost. The total number of bioreactors required per batch cycle, the volume of each bioreactor and the minimum bioreactor cost were estimated based on the study of Koutinas et al. [50] and Dheskali et al. [42] using the optimal succinic acid production efficiencies in batch and continuous cultures. The DSP used in this study has been presented by Alexandri et al. [51]. The experimental succinic acid crystal purity achieved in this study using the fermentation broth derived from OFMSW-based cultures was more than $99 \%$. Individual DSP stages resulted in similar mass balances to the ones reported by Alexandri et al. [51]. The UniSim software was used for the estimation of mass and energy balances to design and simulate the whole bioprocess. In the case of DSP, the removal of biomass via centrifugation was carried out assuming $100 \%$ removal of the microbial mass with $50 \%$ 
moisture content. The biomass-free liquid stream is then treated with activated carbon for decolorization. The mass removed in this step is insignificant, thus only energy requirements were taken into consideration. Treatment with cation exchange resins was subsequently carried out for the removal of $\mathrm{Na}^{+}$and $\mathrm{Mg}^{+2}$ and the acidification of organic acid salts into their acid form. Evaporation of the acidified liquid stream is carried out using a mechanical vapor recompression forced circulation evaporator system to produce a concentrated solution of succinic acid $(216 \mathrm{~g} / \mathrm{L})$. The simulation of the DSP process indicates that $76 \%$ of the acetic acid and $89 \%$ of the formic acid were removed in the evaporation step.

The concentrated succinic acid rich liquid stream produced via evaporation is processed via crystallization at $4{ }^{\circ} \mathrm{C}$ resulting in $84 \%$ recovery of succinic acid crystals. In order to increase the succinic acid purity (95\%) achieved in the first crystallization step, recrystallization was applied by adding water with the final succinic acid purity exceeding $99 \%$. The liquid stream remaining after crystallization containing the non-precipitated succinic acid was recirculated in the evaporation step in order to reduce succinic acid losses and achieve recovery yields of around $95 \%$. The succinic acid crystals were dried at $70^{\circ} \mathrm{C}$ using a spray dryer.

Preliminary techno-economic evaluation has been carried out considering annual plant operation of 8300 $\mathrm{h}$ at varying plant capacities. The cost of manufacture for succinic acid production excluding depreciation $\left(\mathrm{COM}_{\mathrm{WOD}}\right)$ and the discounted cash flow analysis have been estimated using the methodology presented by Koutinas et al. [50]. The following equation has been used for the estimation of $\mathrm{COM}_{\mathrm{wOD}}$ as proposed by Turton et al. [52]:

$\mathrm{COM}_{\mathrm{wOD}}=0.18 * \mathrm{FCl}+2.73 * \mathrm{COL}+1.23 *\left(C_{R M}+C_{U T}\right)$

where $F C /$ is the fixed capital investment, $C_{O L}$ is the cost of operating labour, $C_{R M}$ is the cost of raw materials and $C_{U T}$ is the cost of utilities. The estimation of $C_{O L}, C_{R M}$ and $C_{U T}$ has been described by Koutinas et al. [50]. The estimation of $\mathrm{FCl}$ is based on the estimation of the equipment purchase cost multiplied with a Lang factor of 5 . The equipment purchase cost is estimated by sizing all unit operation using the methodology described by Koutinas et al [50].

After the estimation of $\mathrm{COM}_{\mathrm{woD}}$, the discounted cash flow analysis was carried out in order to estimate the production cost of OFMSW hydrolysate per t of sugars considering two MSP for bio-based succinic acid $\left(2.94 \$ / \mathrm{kg}_{\text {SA }}\right.$ and $\left.2.5 \$ / \mathrm{kg}_{\mathrm{SA}}\right)$. The calculations were carried out by iterating the $C O M_{\text {woD,total }}$ of the whole process (including $\mathrm{COM}_{\text {WoD,SA }}$ for succinic acid production and $\mathrm{COM}_{\text {WOD,OFMSW }}$ for OFMSW hydrolysate production) until the net present value becomes zero at the end of the project life time. The iterating process is illustrated in Figure 9.

\section{Abbreviations}

OFMSW: Organic fraction of municipal solid waste, MSW: Municipal solid waste, YE: Yeast extract, CSL: Corn steep liquor, 5-HMF: 5- hydroxymethylfurfural, HRT: Hydraulic retention time, PEP: phosphoenolpyruvate carboxykinase, FCl: Fixed capital investment, COM: Cost of manufacture, DSP: 
Downstream separation and purification, MSP: Minimum selling price, NPV: Net present value, Glu: Glucose, Suc: Sucrose, Fru: Fructose, Arab: Arabinose, Glyc: Glycerol, SA: Succinic acid, LA: Lactic acid, FA: Formic acid, AA: Acetic acid, OD: Optical density, FAN: Free amino nitrogen, IP: Inorganic phosphorous

\section{Declarations}

\section{Acknowledgements}

Not applicable.

\section{Funding}

The authors wish to acknowledge financial support from the Bio Based Industries Joint Undertaking under the European Union's Horizon 2020 research and innovation programme under grant agreement No 745828 entitled "Chemical building blocks from versatile MSW biorefinery" (Acronym: PERCAL project).

\section{Authors' contributions}

Eleni Stylianou and Maria Cruz performed the experiments. Dimitrios Ladakis performed the preliminary techno-economic evaluation of the selected processes. Apostolis Koutinas, Chrysanthi Pateraki, Marcos Latorre and Caterina Coll designed and supervised the experiments. Eleni Stylianou, Chrysanthi Pateraki and Marcos Latorre wrote the manuscript. Apostolis Koutinas, Caterina Coll and Chrysanthi Pateraki revised the manuscript. All authors read and approved the final manuscript.

\section{Ethics approval and consent to participate}

Not applicable.

\section{Consent for publication}

Not applicable.

\section{Availability of data and materials}

Not applicable.

\section{Competing interests}

The authors declare no conflict of interest.

\section{References}

1. Eurostat, https://ec.europa.eu/eurostat/ (visited on 10/12/2019)

2. EUR-lex, https://eur-lex.europa.eu/legal-content/EN/TXT/? uri=uriserv:OJ.L_.2018.150.01.0109.01.ENG 
3. European Environment Agency, 2013. https://www.eea.europa.eu (visited on 10/12/2019)

4. Pagliano G, Ventorino V, Panico A, Pepe O. Integrated systems for biopolymers and bioenergy production from organic waste and by-products: A review of microbial processes. Biotechnol Biofuels. 2017;10:113.

5. Colombo B, Favini F, Scaglia B, Sciarria TP, D’Imporzano G, Pognani M, Alekseeva A, Eisele G, Cosentino C, Adani F. Enhanced polyhydroxyalkanoate (PHA) production from the organic fraction of municipal solid waste by using mixed microbial culture. Biotechnol Biofuels. 2017;10:201.

6. Bernat K, Cydzik-Kwiatkowska A, Zielińska M, Wojnowska-Baryła I, Wersocka J. Valorisation of the selectively collected organic fractions of municipal solid waste in anaerobic digestion. Biochem Eng J. 2019;148:87-96.

7. Matsakas L, Kekos D, Loizidou M, Christakopoulos P. Utilization of household food waste for the production of ethanol at high dry material content. Biotechnol Biofuels. 2014;7:4.

8. López-Gómez JP, Latorre-Sánchez M, Unger P, Schneider R, Lozano CC, Venus J. Assessing the organic fraction of municipal solid wastes for the production of lactic acid. Biochem Eng J. 2019;150.

9. Babaei M, Tsapekos P, Alvarado-Morales M, Hosseini M, Ebrahimi S, Niaei A, Angelidaki I. Valorization of organic waste with simultaneous biogas upgrading for the production of succinic acid. Biochem Eng J. 2019;147:136-145.

10. Pateraki C, Patsalou M, Vlysidis A, Kopsahelis N, Webb C, Koutinas A, Koutinas M. Actinobacillus succinogenes: Advances on succinic acid production and prospects for development of integrated biorefineries. Biochem Eng J. 2016;112:285-303.

11. Bio-based News, http://news.bio-based.eu/succinic-acid-new-bio-based-building-block-with-a-hugemarket-and-environmental-potential/ (visited on 10/12/2019)

12. Taylor R, Nattrass L, Alberts G, Robson P, Chudziak C, Bauen A, et al. Springer J, Bakker R, van Ree R. From the sugar platform to biofuels and biochemicals. Final report for the European Commission Directorate-General Energy NoENER/C2/423-2012/SI2.673791. (2015)

13. Chemical and Engineering News, https://cen.acs.org/content/cen/articles/97/i12/Succinic-acidonce-biobased-chemical.html (visited on 10/12/2019)

14. Sarnia This Week, https://www.sarniathisweek.com/news/local-news/lcy-biosciences-aims-torestart-idle-plant (visited on 10/12/2019)

15. Li C, Gao S, Li X, Yang X, Lin CSK. Efficient metabolic evolution of engineered Yarrowia lipolytica for succinic acid production using a glucose-based medium in an in situ fibrous bioreactor under low-pH condition. Biotechnol Biofuels 2018;11:236.

16. Leung CCJ, Cheung ASY, Zhang AYZ, Lam KF, Lin CSK. Utilisation of waste bread for fermentative succinic acid production. Biochem Eng J. 2012;65:10-15.

17. Kwan TH, Hu Y, Lin CSK. Valorisation of food waste via fungal hydrolysis and lactic acid fermentation with Lactobacillus casei Bioresour Technol. 2016;217:129-136. 
18. Kwan TH, Ong KL, Haque MA, Kwan WH, Kulkarni SS, Lin CS. Valorisation of food and beverage waste via saccharification for sugars recovery. Bioresour Technol. 2018;255:67-75.

19. Ladakis D, Michailidi K, Vlysidis A, Koutinas A, Kookos IK. . Biochem Eng J. 2018;137:262-272.

20. Bradfield MFA, Mohagheghi A, Salvachúa D, Smith H, Black BA, Dowe N, Beckham GT, Nicol W. Continuous succinic acid production by Actinobacillus succinogenes on xylose-enriched hydrolysate. Biotechnol Biofuels. 2015;8:181.

21. van Wyk JP. Biotechnology and the utilization of biowaste as a resource for bioproduct, Trends in Biotechnol. 2001;19:172-177.

22. García AJ, Esteban MB, Márquez MC, Ramos P. Biodegradable municipal solid waste: Characterization and potential use as animal feedstuffs. Waste Management, 2005;25:780-787.

23. Salvachúa D, Mohagheghi A, Smith H, Bradfield MFA, Nicol W, Black BA, Biddy MJ, Dowe N, Beckham GT. Succinic acid production on xylose-enriched biorefinery streams by Actinobacillus succinogenesin batch fermentation. Biotechnol Biofuels 2016;9:28.

24. Li C, Ong KL, Yang X, Lin CSK. Bio-refinery of waste streams for green and efficient succinic acid production by engineered Yarrowia lipolytica without pH control. Chem Eng J. 2019;371:804-812.

25. Leung CCJ, Cheung ASY, Zhang AYZ, Lam KF, Lin CSK. Utilisation of waste bread for fermentative succinic acid production. Biochem Eng J. 2012;65:10-15.

26. Zhang AYZ, Sun Z, Leung CCJ, Han W, Lau KY, Li M, Lin CSK. Valorisation of bakery waste for succinic acid production. Green Chem. 2013;15:690-695.

27. Liu YP, Zheng P, Sun ZH, Ni Y, Dong JJ, Zhu LL. Economical succinic acid production from cane molasses by Actinobacillus succinogenes. Bioresource Technol. 2008;99:1736-1742.

28. Lin SKC, Du C, Koutinas A, Wang R, Webb C. Substrate and product inhibition kinetics in succinic acid production by Actinobacillus succinogenes. Biochem Eng J. 2008;41:128-135.

29. Pateraki C, Almqvist $H$, Ladakis D, Lidén G, Koutinas AA, Vlysidis A. Modelling succinic acid fermentation using a xylose based substrate. Biochem Eng J. 2016;114:26-41.

30. Podkovyrov M, Zeikus JG, Purification and characterization of phosphoenolpyruvate carboxykinase, a catabolic $\mathrm{CO}_{2}$-fixing enzyme, from Anaerobiospirillum succiniciproducens. J Gen Microbiol. 2000;139:223-228.

31. McKinlay JB, Vieille C. 13C-metabolic flux analysis of Actinobacillus succinogenes fermentative metabolism at different $\mathrm{NaHCO}_{3}$ and $\mathrm{H}_{2}$ Metab Eng. 2008;10:55-68.

32. McKinlay JB, Zeikus JG, Vieille C. Insights into Actinobacillus succinogenes fermentative metabolism in a chemically defined growth medium. Appl Environ Microbiol. 2005;71:6651-6656.

33. Brink HG, Nicol W. Succinic acid production with Actinobacillus succinogenes: rate and yield analysis of chemostat and biofilm cultures. Microb Cell Fact. 2014;13:1

34. Zheng P, Fang L, Xu Y, Dong JJ, Ni Y, Sun ZH. Succinic acid production from corn stover by simultaneous saccharification and fermentation using Actinobacillus succinogenes. Bioresour Technol. 2010;101:7889-7894. 
35. Chen KQ, Li J, Ma JF, Jiang M, Wei P, Liu ZM, Ying HJ. Succinic acid production by Actinobacillus succinogenes using hydrolysates of spent yeast cells and corn fiber. Bioresour Technol. 2011;102:1704-1708.

36. Urbance SE, Pometto AL, DiSpirito AA, Denli Y. Evaluation of succinic acid continuous and repeatbatch biofilm fermentation by Actinobacillus succinogenes using plastic composite support bioreactors. Appl Microbiol Biotechnol. 2004;65:664-670.

37. Bradfield MFA, Nicol W. Continuous succinic acid production by Actinobacillus succinogenes in a biofilm reactor: Steady-state metabolic flux variation. Biochem Eng J. 2014;85:1-7.

38. van Heerden CD, Nicol W. Continuous succinic acid fermentation by Actinobacillus succinogenes. Biochem Eng J. 2013;73:5-11.

39. Maharaj K, Bradfield MFA, Nicol W. Succinic acid-producing biofilms of Actinobacillus succinogenes: reproducibility, stability and productivity. Appl Microbiol Biotechnol. 2014;98:7379-7386.

40. Ferone M, Raganati F, Ercole A, Olivieri G, Salatino P, Marzocchella A. Continuous succinic acid fermentation by Actinobacillus succinogenes in a packed - bed biofilm reactor. Biotechnol Biofuels. 2018;11:138.

41. Yan Q, Zheng P, Tao ST, Dong JJ. Fermentation process for continuous production of succinic acid in a fibrous bed bioreactor. Biochem Eng J. 2014;91:92-98.

42. Dheskali E, Michailidi K, de Castro AM, Koutinas AA, Kookos IK. Optimal design of upstream processes in biotransformation technologies. Bioresource Technol. 2017;224:509-514.

43. Harland BF, Harland J. Fermentative reduction of phytate in rye, white and whole wheat breads. Cereal Chem. 1980;57:226-229.

44. Lie S. The EBC-ninhydrin method for determination of free alpha amino nitrogen. J Instit Brew. 1973;79:37.

45. Sluiter A, Hames B, Ruiz R, Scarlata C, Sluiter J, Templeton, D, Crocker D. Determination of Structural Carbohydrates and Lignin in Biomass. Technical Report. NREL/TP-510-42618 (2005)

46. Sluiter A, Hames B, Hyman D, Payne C, Ruiz R, Scarlata C, Sluiter J, Templeton D, Wolfe J. Determination of Total Solids in Biomass and Total Dissolved Solids in Liquid Process Samples. Technical Report. NREL/TP-510-42621 (2008)

47. Sluiter A, Hames B, Ruiz R, Scarlata C, Sluiter J, Templeton D. Determination of Ash in biomass. Technical Report. NREL/TP-510-42622 (2005)

48. Laurence D, Melton and Bronwen G. Smith Current Protocols in Food Analytical Chemistry E3.3.1E3.3.4 Copyright (C) 2001 by John Wiley \& Sons, Inc. (2001)

49. Sluiter A, Ruiz R, Scarlata C, Sluiter J, Templeton D. Determination of extractives in biomass. Technical Report. NREL/TP-510-42619. (2005)

50. Koutinas AA, Yepez B, Kopsahelis N, Freire DM, de Castro AM, Papanikolaou S, Kookos IK. Technoeconomic evaluation of a complete bioprocess for 2,3-butanediol production from renewable resources. Bioresour Technol. 2016;204:55-64. 
51. Alexandri M, Schneider R, Papapostolou H, Ladakis D, Koutinas A, Venus J. Restructuring the conventional sugar beet industry into a novel biorefinery: Fractionation and bioconversion of sugar beet pulp into succinic acid and value-added coproducts. ACS Sustainable Chem Eng. 2019;7:65696579.

52. Turton R, Baile RC, Whiting WB, Shaeiwitz JA, Bhattacharyya D. Analysis, synthesis, and design of chemical processes, 5th edn. Prentice Hall, New Jersey; 2018

\section{Tables}

Table 1 Characterization of OFMSW samples from real MSW treatment plant

\begin{tabular}{lcccc}
\hline \multicolumn{1}{c}{$\begin{array}{c}\text { COMPONENTS } \\
(\%, \text { dry basis) }\end{array}$} & \multicolumn{2}{c}{ Sorted biowaste } & \multicolumn{2}{c}{ Unsorted biowaste } \\
& Spring/Summer Autumn/Winter Spring/Summer Autumn/Winter \\
\hline Total solids & $31.36 \pm 0.5$ & $16.14 \pm 0.5$ & $43.3 \pm 4$ & $51.61 \pm 0.9$ \\
Ash & $6.25 \pm 0.3$ & $7.59 \pm 0.7$ & $19.2 \pm 0.7$ & $23.07 \pm 1.1$ \\
\hline Fats and waxes & $1.57 \pm 0.9$ & $3.15 \pm 1.2$ & $4.59 \pm 0.7$ & $5.86 \pm 0.8$ \\
\hline Water solubles & $36.20 \pm 0.4$ & $42.56 \pm 0.3$ & $27.9 \pm 2.2$ & $15.59 \pm 1.9$ \\
\hline Pectin & $15.87 \pm 2.9$ & $18.25 \pm 0.4$ & $10.1 \pm 2.0$ & $12.19 \pm 0.8$ \\
\hline Lignin & $9.47 \pm 0.6$ & $8.00 \pm 1.2$ & $5.64 \pm 0.8$ & $11.02 \pm 1.2$ \\
\hline Glucan (Cellulose and starch) & $39.64 \pm 5.4$ & $39.83 \pm 0.5$ & $36.57 \pm 2.9$ & $25.06 \pm 0.3$ \\
\hline Xylan & $0.2 \pm 0.01$ & $1.92 \pm 0.5$ & $5.14 \pm 0.2$ & $8.67 \pm 0.4$ \\
\hline Protein & $10.15 \pm 0.2$ & $8.75 \pm 0.5$ & $7.4 \pm 0.7$ & $7.0 \pm 0.4$ \\
\hline Starch & $4.71 \pm 1.5$ & $5.31 \pm 0.9$ & $4.36 \pm 0.3$ & $4.17 \pm 0.7$ \\
\hline Inert materials (\%, wet basis) & $4 \%$ & $5 \%$ & $25 \%$ & $36 \%$ \\
\hline
\end{tabular}

Table 2 Composition of liquid and solid fractions of OFMSW hydrolysates 


\begin{tabular}{|c|c|}
\hline Components of solid and liquid OFMSW hydrolysate fractions & Range \\
\hline Total dry weight $(\mathrm{g} / \mathrm{L})$ & $114.17-118.81$ \\
\hline \multicolumn{2}{|l|}{ Liquid fraction of OFMSW hydrolysate } \\
\hline $\mathrm{pH}$ & $4.36-5.18$ \\
\hline Free amino nitrogen $(\mathrm{mg} / \mathrm{L})$ & $203.6-638.7$ \\
\hline Inorganic phosphorus (mg/L) & $100.6-553$ \\
\hline Kjeldahl protein content (\%) & $1.72-2.86$ \\
\hline Sugars $(g / L)$ & $31.2-107.3$ \\
\hline Sucrose & $0.25-3.58$ \\
\hline Glucose & $25.4-75.9$ \\
\hline Xylose & $3.95-7.6$ \\
\hline Galactose & $0.2-1.4$ \\
\hline Arabinose & $0.5-1.5$ \\
\hline Mannose & $0.2-0.8$ \\
\hline Fructose & $0.1-15.5$ \\
\hline Glycerol & $0.63-1$ \\
\hline Total organic acids $(g / L)$ & $12.2-22.5$ \\
\hline Lactic acid & $10.7-18.6$ \\
\hline Acetic acid & $1.5-3.7$ \\
\hline \multicolumn{2}{|l|}{ Solid fraction of OFMSW hydrolysate (\% dry basis) } \\
\hline Ash content & $5.7-25$ \\
\hline Protein content & $7.0-19.85$ \\
\hline Lipid content & $6.8-7.6$ \\
\hline Extractives & $33.23-33.34$ \\
\hline Lignin & $16.92-27.39$ \\
\hline Cellulose & $9.07-9.46$ \\
\hline \multirow[t]{4}{*}{ Hemicellulose } & $6.64-6.91$ \\
\hline & $0.91-0.94$ \\
\hline & $4.46-4.52$ \\
\hline & - \\
\hline
\end{tabular}

Table 3 Fermentation efficiency of B. succiniciproducens and A. succinogenes batch cultures carried out at three initial concentrations of commercial carbon sources and OFMSW hydrolysate 


\begin{tabular}{|c|c|c|c|c|c|}
\hline $\begin{array}{c}\text { Initial \& consumed carbon } \\
\text { sources }{ }^{*} \\
(\mathrm{~g} / \mathrm{L})\end{array}$ & Medium & $\begin{array}{l}\text { Succinic } \\
\text { acid } \\
(\mathrm{g} / \mathrm{L})\end{array}$ & $\begin{array}{l}\text { Yield } \\
* \\
(\mathrm{~g} / \mathrm{g})\end{array}$ & $\begin{array}{l}\text { Productivity } \\
\text { (g/L/h) }\end{array}$ & $\begin{array}{l}\text { By-product : Succinic acid } \\
\text { (g/g) }\end{array}$ \\
\hline \multicolumn{6}{|c|}{ Basfia succiniciproducens } \\
\hline $30(27.8)$ & Commercial & 12.5 & 0.45 & 0.44 & 1.19 \\
\hline $30(31.3)$ & OFMSW & 14.4 & 0.46 & 0.64 & 0.90 \\
\hline $50(51.7)$ & Commercial & 26.9 & 0.52 & 0.45 & 0.66 \\
\hline $50(50.6)$ & OFMSW & 26.8 & 0.53 & 0.85 & 0.88 \\
\hline $80(81.1)$ & Commercial & 35.7 & 0.44 & 0.46 & 0.56 \\
\hline $80(78.9)$ & OFMSW & 37.1 & 0.47 & 0.56 & 0.68 \\
\hline \multicolumn{6}{|c|}{ Actinobacillus succinogenes } \\
\hline $30(30.8)$ & Commercial & 15.4 & 0.5 & 0.6 & 0.71 \\
\hline $30(30.2)$ & OFMSW & 15.7 & 0.52 & 0.52 & 0.71 \\
\hline $50(47.1)$ & Commercial & 27.3 & 0.58 & 0.49 & 0.20 \\
\hline $50(52.7)$ & OFMSW & 29.4 & 0.56 & 0.89 & 0.31 \\
\hline $80(78.2)$ & Commercial & 37.9 & 0.54 & 0.45 & 0.21 \\
\hline $80(77.3)$ & OFMSW & 37.9 & 0.5 & 0.57 & 0.31 \\
\hline
\end{tabular}

* The initial total carbon source concentration is $\pm 5 \%$ of the indicated value, while the consumed carbon source is presented in the brackets; Succinic acid to sugars conversion yield has been calculated based on the quantity $(\mathrm{g})$ of succinic acid produced during fermentation and the quantity $(\mathrm{g})$ of total sugars added in the bioreactor.

Table 4 Fermentation efficiency of $A$. succinogenes fed-batch cultures carried out using OFMSW hydrolysate

\begin{tabular}{ccccccc}
\hline $\begin{array}{c}\text { Initial \& consumed carbon } \\
\text { sources } \\
(\mathrm{g} / \mathrm{L})\end{array}$ & $\begin{array}{c}\text { Nitrogen } \\
\text { source } \\
(\mathrm{g} / \mathrm{L})\end{array}$ & $\begin{array}{c}\mathrm{MgCO}_{3} \\
(\mathrm{~g} / \mathrm{L})\end{array}$ & $\begin{array}{c}\text { Succinic } \\
\text { acid } \\
(\mathrm{g} / \mathrm{L})\end{array}$ & $\begin{array}{c}\text { Yield } \\
{ }^{*}\end{array}$ & $\begin{array}{c}\text { Productivity } \\
(\mathrm{g} / \mathrm{g})\end{array}$ & $\begin{array}{c}\text { By-product: Succinic } \\
\text { acid }(\mathrm{g} / \mathrm{L} / \mathrm{h})\end{array}$ \\
\hline $50(57.9)$ & $5 \mathrm{~g} / \mathrm{L} \mathrm{CSL}$ & 5 & 28.7 & 0.50 & 0.41 & 0.37 \\
$50(68.4)$ & $5 \mathrm{~g} / \mathrm{L} \mathrm{YE}$ & 5 & 34.3 & 0.50 & 0.75 & 0.59 \\
\hline $50(55.1)$ & - & 5 & 31.1 & 0.56 & 0.62 & 0.30 \\
$50(57.1)$ & - & 10 & 31.7 & 0.56 & 0.72 & 0.25 \\
$50(58.4)$ & - & 20 & 34.8 & 0.60 & 0.79 & 0.25 \\
\hline
\end{tabular}

* Consumed carbon source is presented in the brackets; Succinic acid to sugars conversion yield has been calculated based on quantity $(\mathrm{g})$ of succinic acid produced during fermentation and the quantity $(\mathrm{g})$ of total sugars added in the bioreactor. 

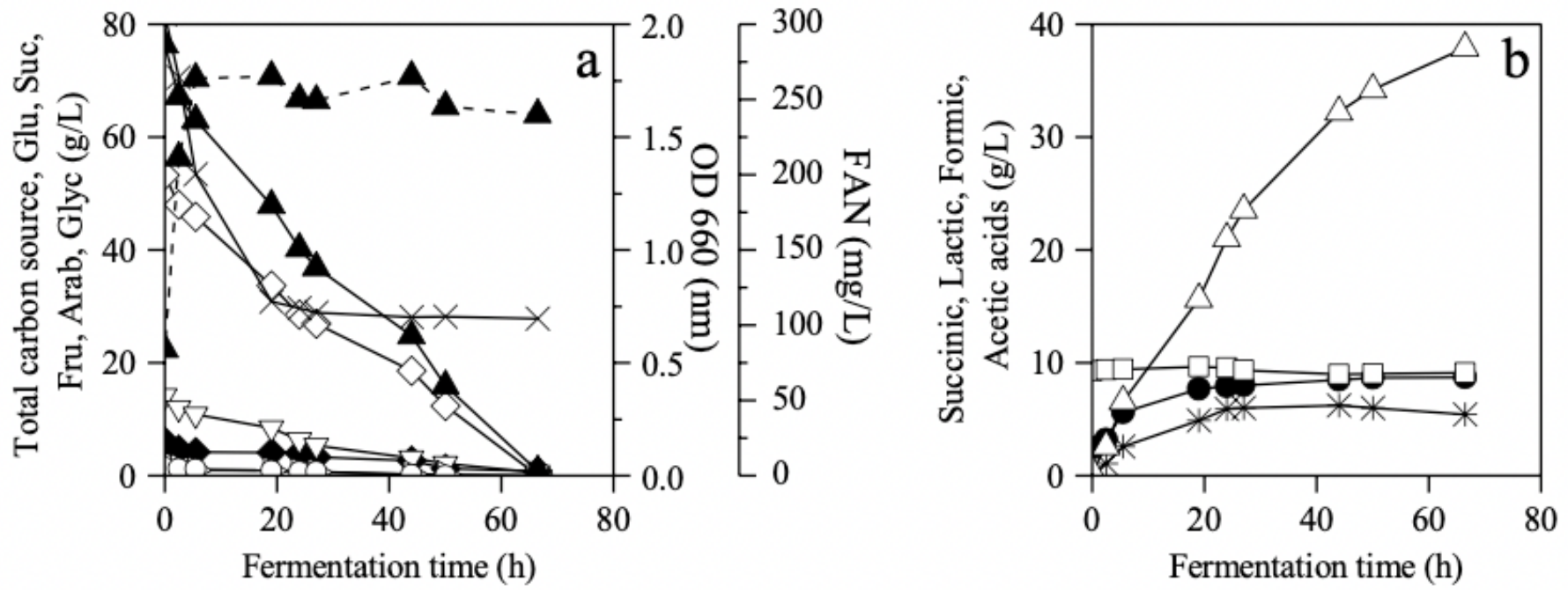

Figure 1

Carbon source consumption, optical density (OD) and metabolic product synthesis during batch fermentation of A. succinogenes using OFMSW hydrolysate at initial total carbon source concentration of

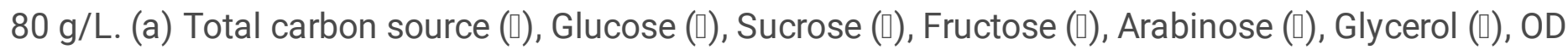

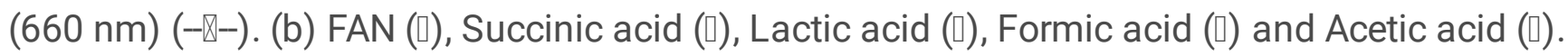



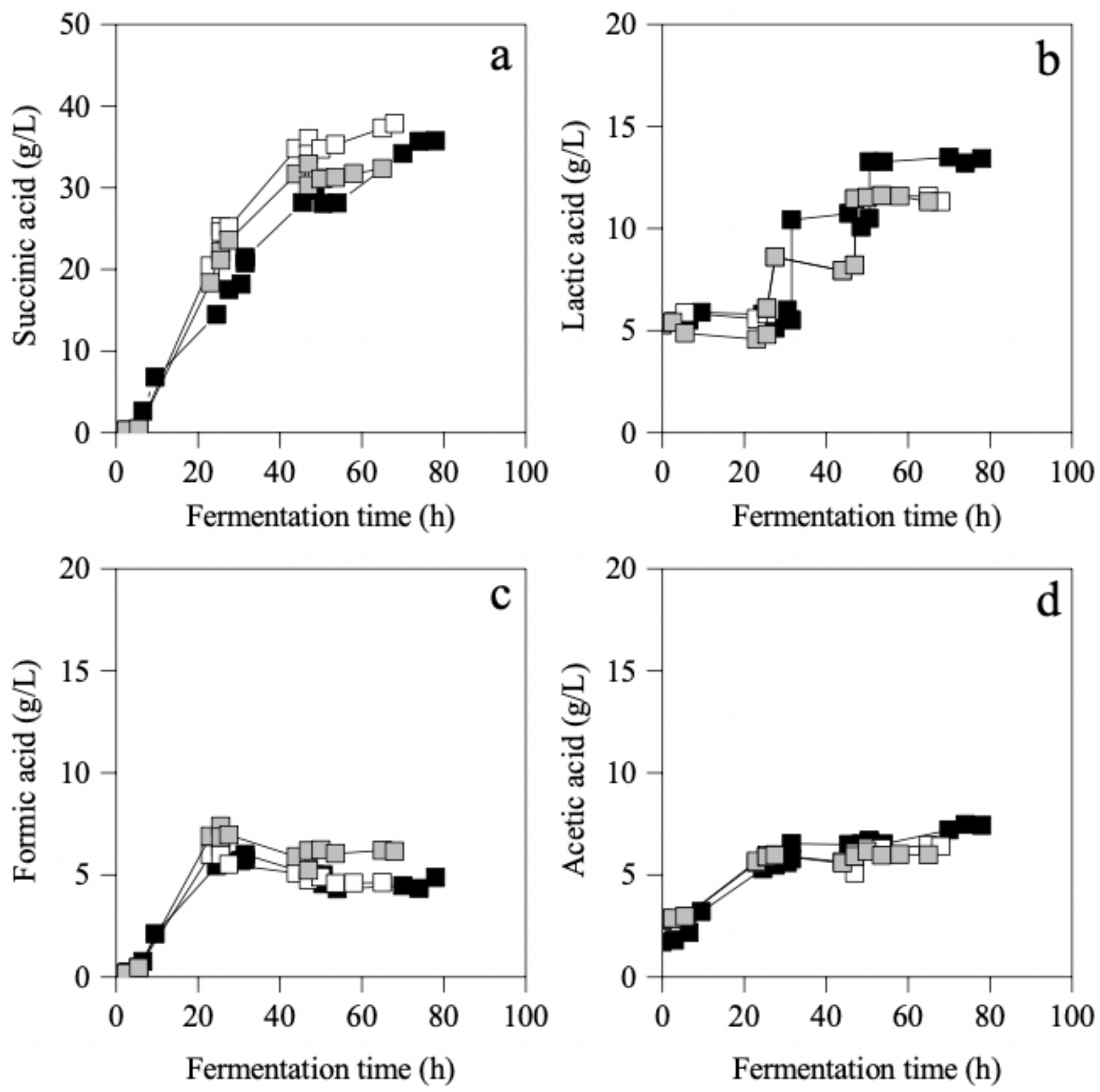

Figure 2

Succinic acid (a), formic acid (c) and acetic acid (d) production and lactic acid (b) accumulation in fedbatch fermentations of A. succinogenes using OFMSW hydrolysate supplemented with three different

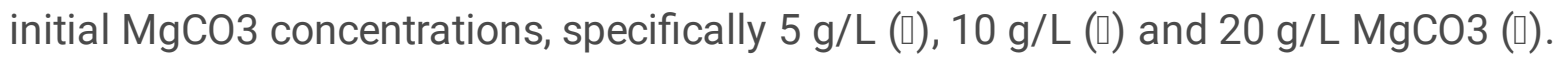



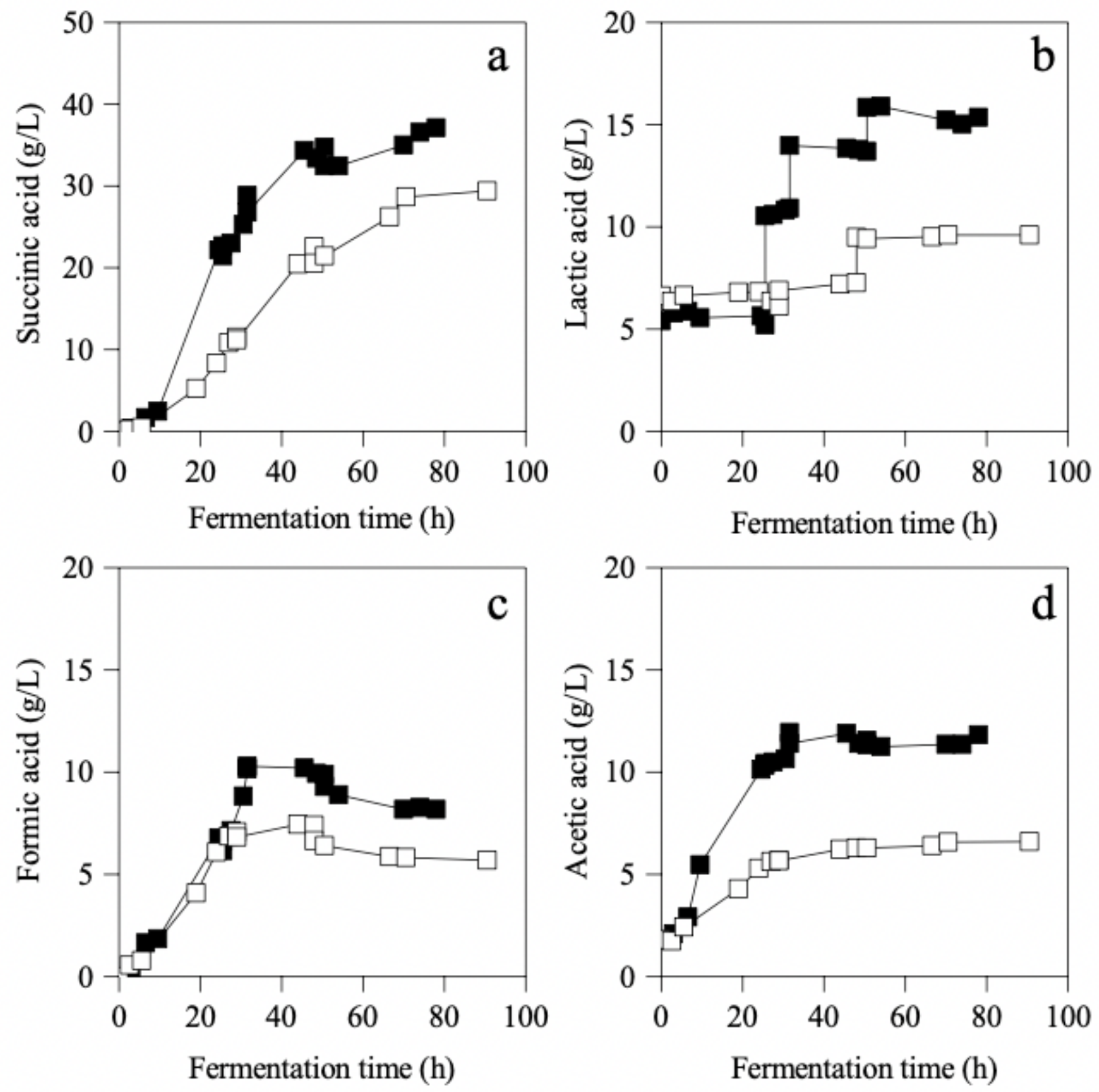

Figure 3

Succinic acid (a), formic acid (c) and acetic acid (d) production and lactic acid (b) accumulation in fedbatch fermentations of $\mathrm{A}$. succinogenes using OFMSW hydrolysate supplemented with $5 \mathrm{~g} / \mathrm{L} \mathrm{MgCO}$ and either $5 \mathrm{~g} / \mathrm{L}$ yeast extract ( () or $5 \mathrm{~g} / \mathrm{L} \mathrm{CSL}(\square)$. 

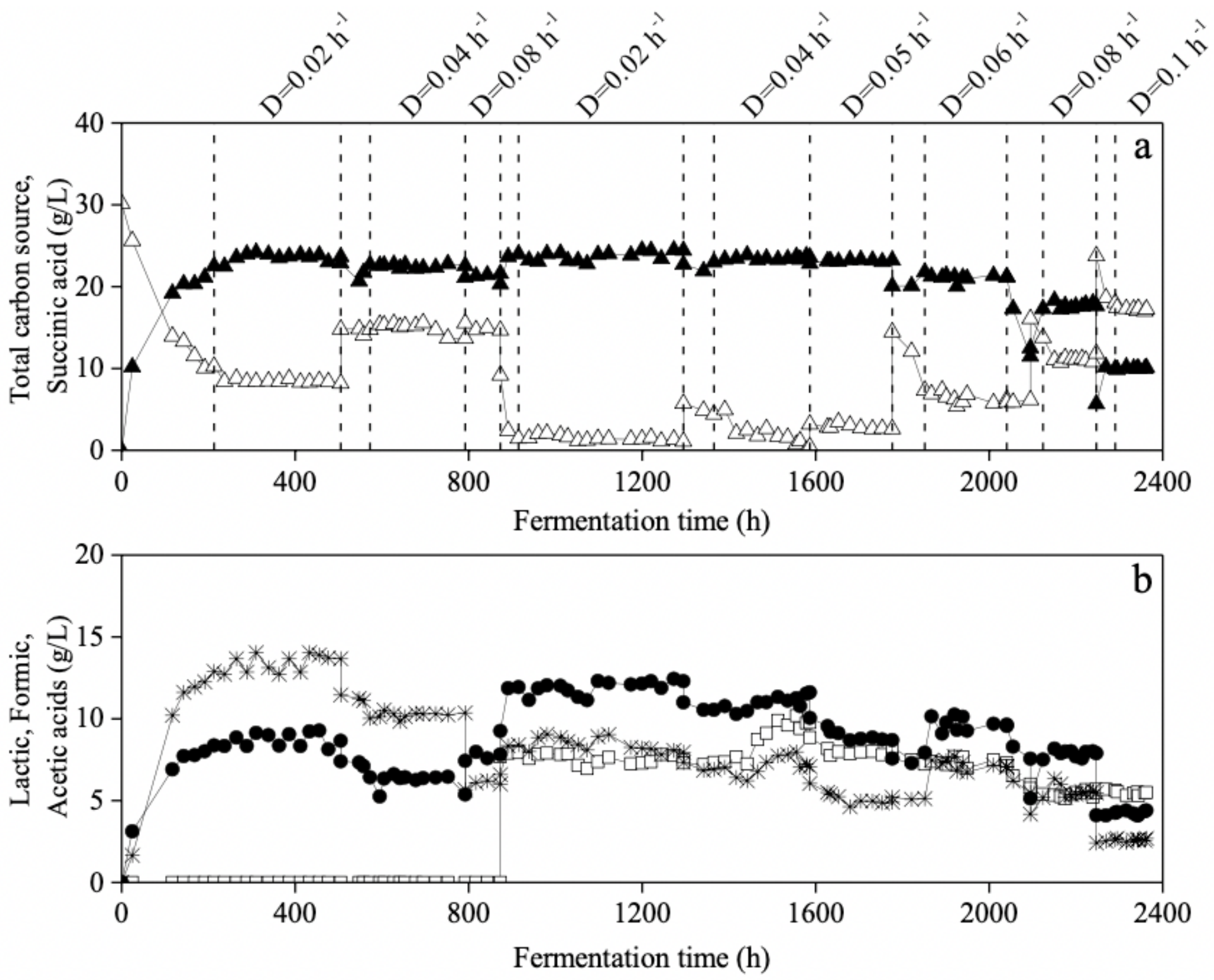

Figure 4

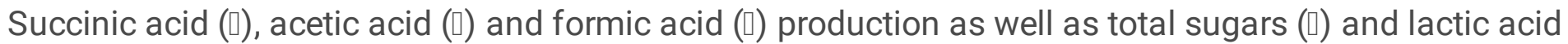
$(\bigotimes)$ accumulation during continuous fermentation of A. succinogenes at different dilution rates using either commercial carbon source (until $900 \mathrm{~h}$ ) or OFMSW hydrolysate (until $2400 \mathrm{~h}$ ) 

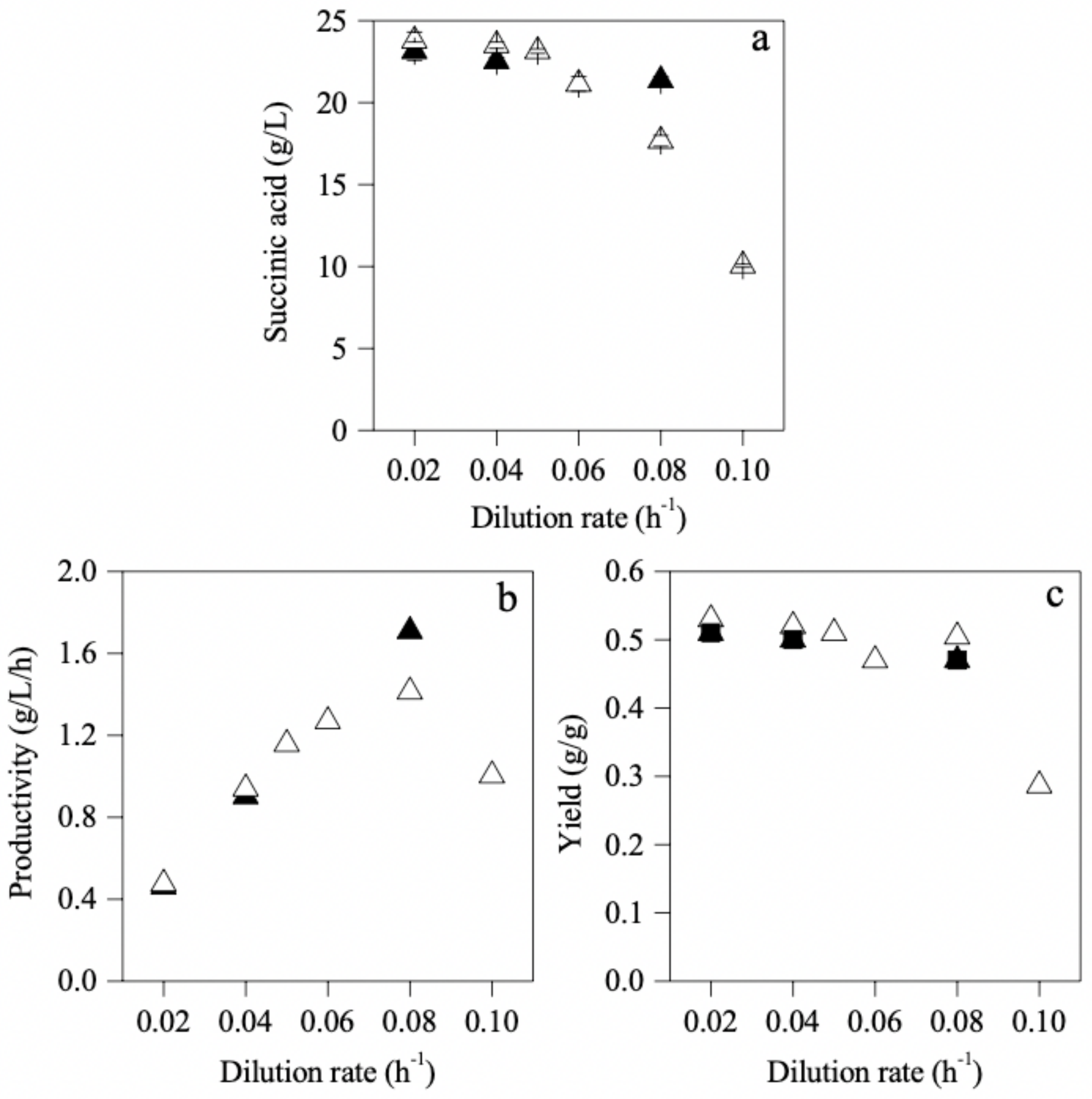

Figure 5

Succinic acid concentration (a), productivity (b) and yield (c) achieved during A. succinogenes continuous cultures using OFMSW hydrolysate (unfilled symbols) and synthetic medium (filled symbols) at different dilution rates. Data represent the average values of the steady-states at each dilution rate. 

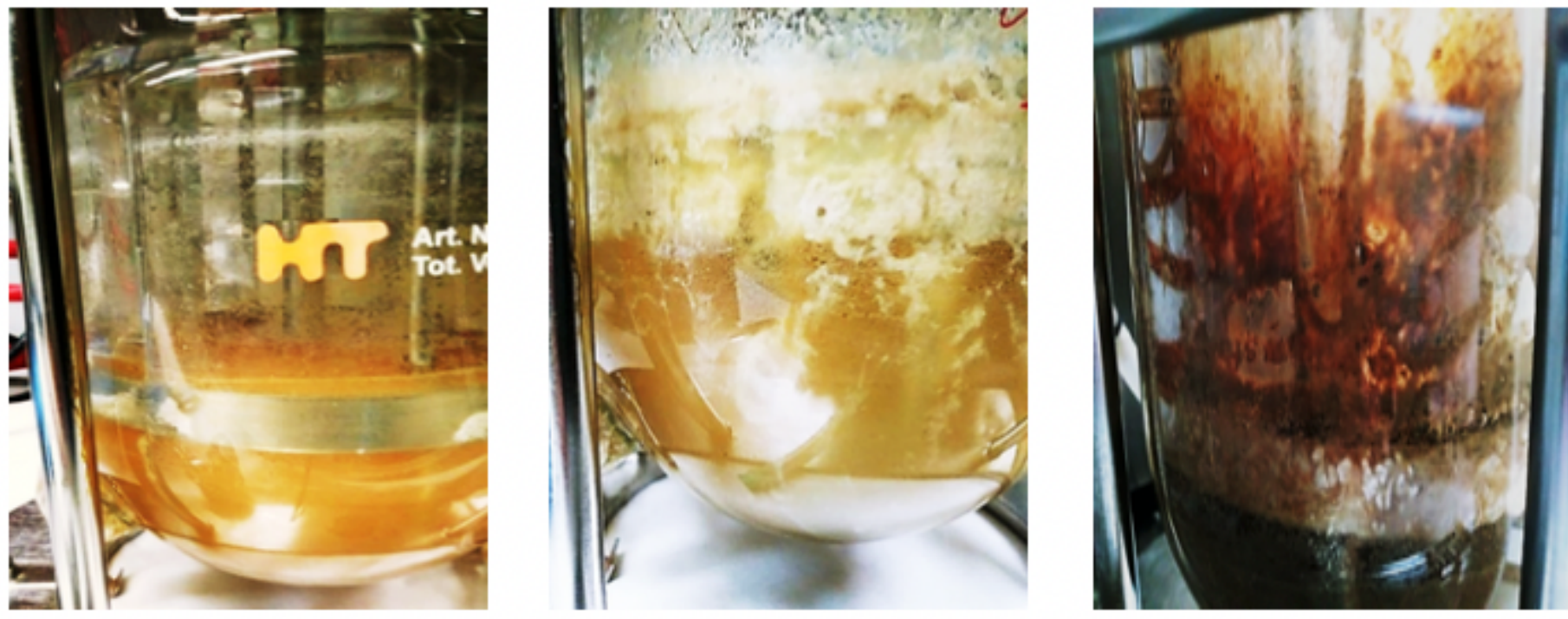

Figure 6

Wall growth and biofilm formation in continuous A. succinogenes culture at the beginning of fermentation (left), during feeding with commercial sugars (middle) and during feeding with OFMSW hydrolysate (right).
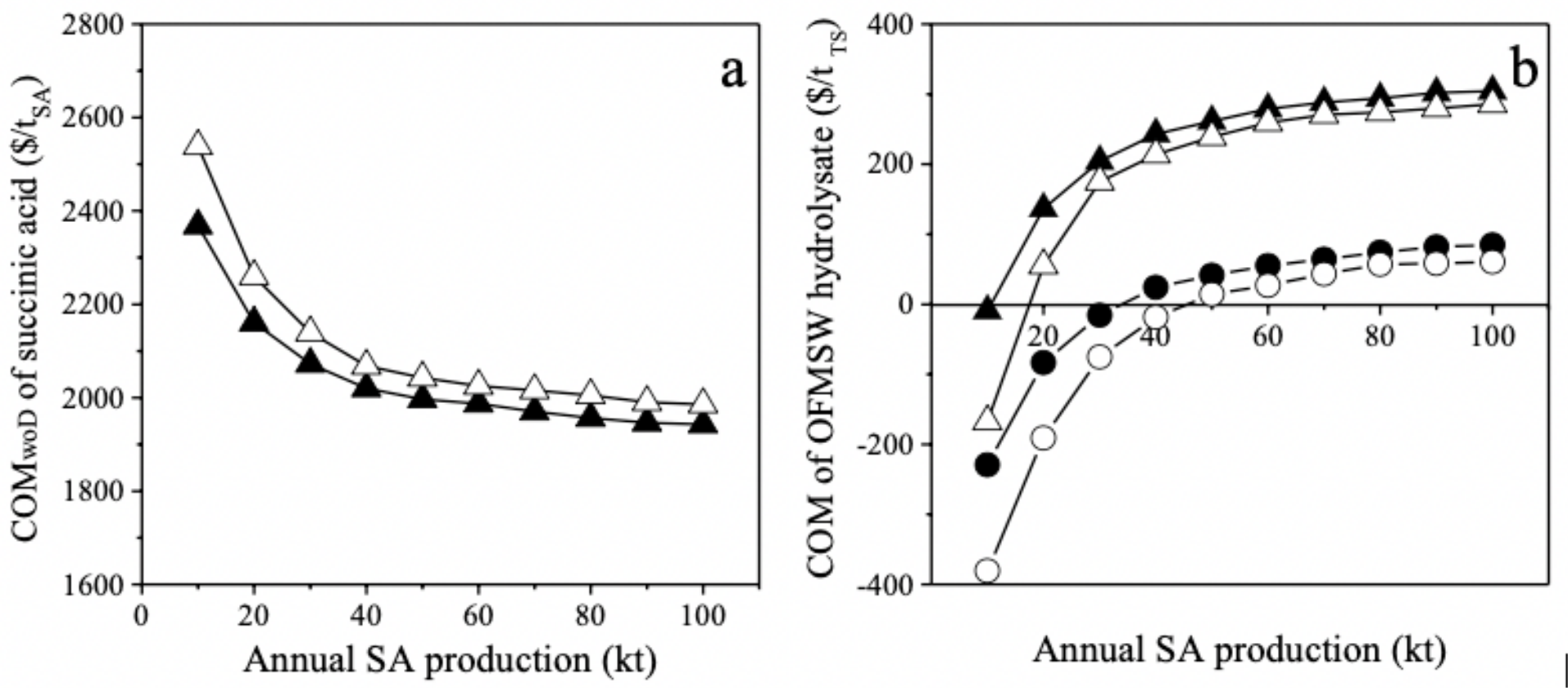

Figure 7

Cost of manufacture of succinic acid (\$/tSA) in different annual production capacities (a) and cost of manufacture of OFMSW hydrolysate per t sugars (\$/tTS) in different annual production capacities of succinic acid (b) for continuous ( $(\square)$ and batch () cultures. The OFMSW hydrolysate cost has been estimated considering two different MSP for succinic acid (2.94\$/kgSA and $2.5 \$ / \mathrm{kgSA})$. 

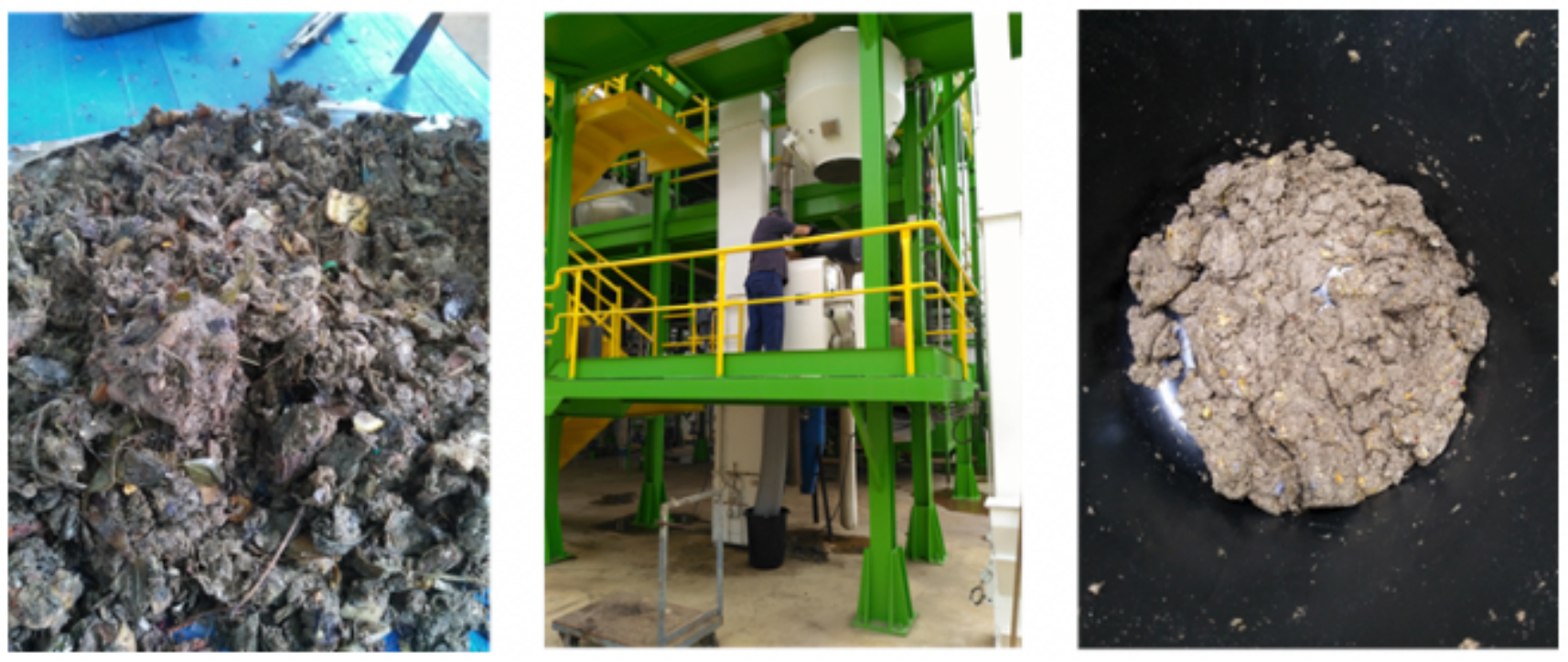

\section{Figure 8}

OFMSW sample from MSW treatment plant after inert materials removal (left), milling facilities in IMECAL's pilot plant (middle), homogenised OFMSW sample after milling (right) ready for characterization and hydrolysis.

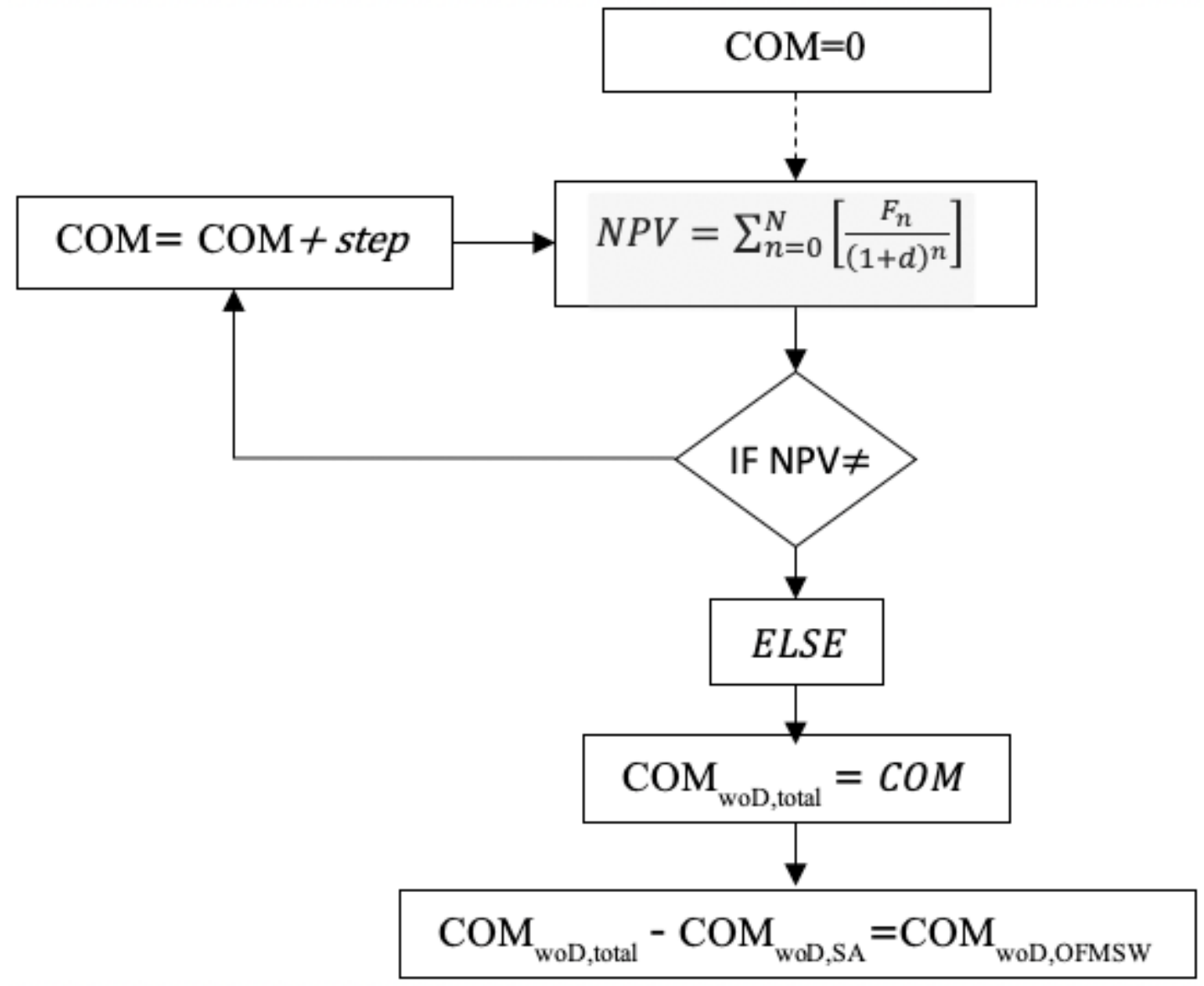

Figure 9 
Schematic diagram for estimation of the OFMSW hydrolysate production cost by iterating the COMwoDTotal and calculating the NPV of the process using two different MSP $(2.94 \$ / \mathrm{kg}$ and $2.50 \$ / \mathrm{kg})$. 